\title{
Large EU banks' capital and liquidity: Relationship and impact on credit default swap spreads
}

\author{
Alex Sclip \\ Department of Economics "Marco Biagi” - University of Modena and Reggio Emilia \\ Viale Berengario 51 - 41121 Modena, Italy \\ alex.sclip@unimore.it \\ Claudia Girardone \\ Essex Business School - University of Essex \\ Colchester, CO4 3 SQ, UK \\ cgirard@essex.ac.uk \\ Stefano Miani \\ Department of Economics and Statistics - University of Udine \\ Via Tomadini 30A - 33100 Udine, Italy \\ stefano.miani@uniud.it
}

\begin{abstract}
$\underline{\text { Abstract }}$
This paper explores the interrelations between bank capital and liquidity and their impact on the market probability of default. We employ an unbalanced panel of large European banks with listed credit default swap (CDS) contracts during the period 2005-2015, which allow us to consider the impact of the recent financial crisis. Our evidence suggests that bank capital and funding liquidity risk as defined in Basel III have an economically meaningful bidirectional relationship. However, the effect on CDS spread is ambiguous. While capital appears to have a relatively large impact on CDS spread changes, liquidity risk is priced only when it falls below the regulatory threshold.
\end{abstract}

Keywords: EU Banks; Capital; Liquidity; Credit Default Swaps (CDS); Financial Crisis.

JEL classification: G21.

Acknowledgements: We wish to thank the Joint-editor, Nathan Joseph, and an anonymous referee for their useful comments and suggestions. We also thank Barbara Casu, Laura Chiaramonte, Giacomo Nocera (discussant), Andrea Paltrinieri, John O.S. Wilson; participants at the FMA conference (Financial Management Association, Lisbon, 2017); IRMC (International Risk Management Conference, Florence, 2017); EFiC (Essex Finance Centre Conference in Banking and Finance, Colchester, 2017); and seminar participants at the University of St Andrews (June 2017). 


\section{Introduction}

In normal times, asset markets are buoyant and funding is readily available. The rapid changes in market conditions in the second half of the 2000s and the financial crisis that ensued have shown that liquidity can dry up very quickly and that it can take a long time to come back. Many large banks in the US and Europe experienced financial difficulties despite meeting the existing regulatory capital requirements because they did not prudently manage their liquidity. With greater liquidity and maturity transformation risk, central banks have had to take action both in money markets and individual institutions. Eventually, the Basel Committee on Banking Supervision (BCBS) proposed two standards for liquidity risk and a revision of capital requirements emphasising the importance of solvency requirements in conjunction with liquidity creation. ${ }^{1}$

The new framework introduced with Basel III implied a shift from a unipolar approach, centred on risk-based measures of capital adequacy, towards a multi-polar one (Haldane, 2015), with multiple regulatory constraints at play, i.e. capital ratios and liquidity ratios. However, if a bank strengthens its capital ratios through the issuance of new equity and the withdrawal of short-term wholesale funding, its liquidity position also improves, since it reduces maturity transformation risk through the increase in the amount of stable funding. Equally, if a bank increases the liquidity of its assets by replacing loans with liquid securities, although its capital ratio remains unchanged, its risk-weighted capital improves since liquid assets have a lower risk weight than illiquid loans. This suggests that if a regulatory approach that accounts for multiple frictions and externalities is no doubt desirable, it may be an issue if it ignores risks that are interconnected. This paper enters this debate with the purpose of exploring the existence of such bidirectional relationship between capital and liquidity risk for a representative sample of large European banking institutions.

The traditional role of banks is to perform maturity transformation. This contributes to efficient resource allocation and credit creation. However, while banks holding riskier assets should strengthen their capital to face unexpected losses from selling some assets at fire-sale prices, banks relying on a higher proportion of unstable funding sources for their activities, may need to hold more liquid assets to deal with liquidity risk. The problem is that banks have weak private incentives to limit excessive reliance on unstable funding of core (often illiquid) assets. Banks may also have private incentives to increase leverage, and to expand their balance sheets relying on relatively cheap and abundant shortterm wholesale funding. Rapid balance sheet growth can weaken the ability of individual banks to respond to liquidity and solvency shocks and, when they fail to internalise the costs associated with

\footnotetext{
${ }^{1}$ For detailed information on the new regulatory requirements, see BCBS (2010a; 2010b; 2014 and 2017).
} 
large funding gaps, this can have systemic implications. A highly interconnected financial system tends to exacerbate these spillovers.

The 2008 global financial crisis has demonstrated the distress that can result from banks having insufficient financial resources in terms of capital or liquidity. It has also highlighted the need to develop models and market indicators that can help identify the weaknesses of large credit institutions in terms of capital and liquidity that can trigger systemic risk. Capital and liquidity may provide incremental information about the banks' credit risk (Chiaramonte and Casu, 2017; Vazquez and Federico, 2015) and using credit default swap (CDS) spreads seem ideal because they give a direct measure of banks' default risk. In particular, bank CDS spreads can be considered a timely indicator of credit risk arising from low quality and inadequate capital and insufficient liquidity buffers. Therefore, the second research question this paper aims to investigate is on the effectiveness of CDS spreads in reflecting information of bank overall credit risk arising from low quality and inadequate capital, as well as insufficient liquidity buffers. More specifically, given the relationship between capital and liquidity analysed in the first part of this study, we explore if and to what extent these two factors separately and jointly contribute to CDS price changes during the crisis period. We expect the interrelation between capital and liquidity to be significantly associated with CDS spreads as higher capital levels reduce a bank's liquidity needs. This in turn increases liquidity creation, as banks invest more in illiquid assets. With this analysis, we aim to contribute to the literature on the usefulness of accounting variables for pricing credit risk, with the caveat that previous studies (e.g. Annaert et al. 2013) use only market factors and typically explain a limited proportion of CDS spread changes. In this study we also provide new insights on how effective CDS contracts are as market indicators of bank weaknesses that could be useful to regulators for prompting pre-emptive corrective actions.

This study contributes to the extant literature in several ways. First, to the best of our knowledge, it is the first to provide not only an empirical investigation of the contemporaneous interaction between capital and liquidity for a sample of European banks but also to extend the analysis to the impact of these variables on CDS spread changes. This approach differs from other studies as they typically focus on either the interrelations between capital and liquidity (e.g., Distinguin, Roulet, and Tarazi, 2013) or the determinants of CDS spread changes (Chiaramonte and Casu, 2013; Hasan, Liuling, and Zhang, 2015). Examining both aspects allows us to shed light on the importance of the nexus between capital and liquidity, and on the extent to which they are priced risk factors on the CDS market. Relative to other approaches, the focus on CDS spreads allows us to infer on the impact on financial stability as their widening are normally associated to increased default risk. It is expected that a finding of a significant interrelation between capital and liquidity will provide support to the current set of reforms that introduced a minimum liquidity requirement concomitant to the capital 
adequacy rules. It could also suggest the need to adopt interacting regulatory instruments if our analysis proved the existence of a bidirectional relationship between capital and liquidity risk.

Second, we employ a sample of large banks operating in Europe over 2005-2015 thereby allowing us to consider the impact of both the global financial crisis and the euro sovereign debt crisis. We focus on large banks because they account for roughly $90 \%$ of aggregate bank liquidity, they typically have an easier access to the lender-of-last resort function and would be first to benefit from safety nets, as noted in Distinguin et al. (2013). As far as we are aware, no other published studies conducted an empirical investigation on the relationship between capital and liquidity in the context of the crisis using CDS spreads as one of the explanatory variables. For example, Distinguin et al. (2013) analyse the period before the financial crisis (2000-2006); Hovarth et al. (2012) use a sample of Czech banks from 2000 to 2010. In addition, while existing studies employ yearly on-balance sheet data, in our paper we rely on quarterly data and we also consider large banks' off-balance sheet exposures which have previously been found as important determinants of liquidity risk management especially in large banks (Ippolito, Peydrò, Polo, and Sette, 2016).

Third, we extend the literature in several directions. This paper explores the relationship between capital and liquidity in a way consistent with the most recent international regulatory framework for banks (Basel III). In particular, we employ two different configurations of the Net Stable Funding Ratio (NSFR) as liquidity measure; and three alternative definitions of capital: the leverage ratio, as expressed in the Basel III Accord, the risk-weighted capital ratios defined in Basel II and a market-based measure of capital. Employing alternative definitions of capital and liquidity is important not only for robustness but also because we expect some measures to produce different results. For example, we envisage that our analysis may cast doubts on the ability of risk-based capital ratios to capture the simultaneous interrelations between capital and liquidity.

After examining the complex interrelations between capital and liquidity, we add to the literature by providing an empirical test to identify whether and to what extent market participants in the derivative (CDS) markets incorporate information on capital and liquidity into CDS spreads. It is expected that if investors exercised market discipline in the banking sector through the assessment of bank risk profiles into CDS spreads, supervisors should detect the weaknesses that can arise from banks having insufficient resources in terms of capital and liquidity indirectly, through the monitoring of derivatives. We focus on the CDS market because participation is dominated by institutional investors that tend to be better informed and equipped to monitor the risk profile of a bank compared to other investors. Volz and Wedow (2011) note that investors exercise market discipline in the CDS market, as they find that prices are positively correlated with banks' risks. We expect capital and 
liquidity to correlate negatively with banks' CDS spreads as banks that are more capitalised and more liquid will have lower credit risk.

Finally, we contribute to the literature on the usefulness of CDS spreads in capturing bank risk positions. In particular, we add to the previous works by Hasan et al. (2015) and Kanagaretnam, Zhang, and Zhang (2016) on the applicability of market-based variables and accounting-based bank fundamentals to explain CDS spread changes. The accounting information used in those studies is mostly based on CAMEL ${ }^{2}$ indicators in which only asset liquidity is considered. In our paper, we fill this gap by using a relatively large set of accounting variables and proxies for funding liquidity risk. Moreover, to the best of our knowledge studies focusing on CDS spread determinants do not include the effects of the sovereign debt crisis.

Our evidence suggests a bidirectional positive relationship between capital and liquidity, thereby supporting the "financial fragility/crowding out of deposits" hypothesis developed in theory (see Section 2.1). Our results also confirm the ability of CDS spreads as a timely indicator of bank risk that can be used by regulators in early warning systems to monitor bank weaknesses. More specifically, we find that capital is an important determinant of CDS spread changes. However, funding liquidity risk is a determinant of CDS spread changes when it is above the minimum regulatory threshold and through the interaction with capital ratios. This suggests that investors evaluate the liquidity profile of a bank and incorporate their assessment in CDS prices.

The remainder of the paper is organised as follows. Section 2 reviews the main literature on the relationship between liquidity risk and capital and on the determinants of CDS spread changes in the banking sector. Section 3 describes the dataset and the variables included in the empirical analysis. Section 4 presents the methodology. Section 5 discusses the results. In Section 6 we perform a battery of robustness checks. Section 7 concludes.

\section{Literature review and hypotheses development}

This paper reconciles two strands of literature: the theories linking bank liquidity to capital (Section 2.1) and studies analysing the CDS spreads determinants of the banking sector (Section 2.2).

\footnotetext{
${ }^{2}$ The Camel rating system is a supervisory rating system developed in the US. The acronym CAMEL stands for: Capital adequacy (C), Asset quality (A), Management quality (M), Earnings potential (E), Liquidity (L).
} 


\subsection{The relationship between liquidity and capital in banks}

Several theoretical papers have examined the relationship between bank capital and liquidity creation. ${ }^{3}$ The theoretical discussion has led to two main contrasting hypotheses: the "financial fragility/crowding out of deposits" hypothesis and the "risk absorption" hypothesis. The former combines two effects on liquidity creation derived from higher capital. On one hand, the financial fragility theory of Diamond and Rajan (2000; 2001), models a relationship bank that channels funds from investors to an entrepreneur. In this model deposits are fragile and prone to runs; so in the presence of uncertainty, bank capital has the crucial role of reducing the probability of insolvency. However, this affects the banks' liquidity creation because with a less fragile capital structure monitoring will be reduced. Therefore, the theory predicts that banks set the optimum level of capital that trades off the benefits of liquidity creation with the costs of distress. On the other hand, capital may also reduce liquidity creation because it "crowds out" deposits. Gorton and Winton $(2010 ; 2017)$ argue that compared to investments in equity capital, deposits are better at protecting from liquidity problems. Therefore, if investors' funds shift from liquid deposits to illiquid equity capital, capital ratios increase but there is a reduction in liquidity. The alternative risk absorption hypothesis is directly linked to the risk transformation role of banks and predicts that liquidity creation entails a risk. The more liquidity is created the higher are the potential losses associated with the transformation of shortterm deposits into long-term illiquid assets. Since the role of capital is to absorb risk and expand banks' risk-bearing capacity, higher capital ratios enhance the ability of banks to create liquidity (Bhattacharya and Thakor, 1993; Allen and Gale, 2004; among others).

Recent literature also suggests a causal relationship that moves from liquidity creation to capital. Again, the literature proposes two conflicting hypotheses: the "liquidity risk" and the "liquidity substitution" hypotheses. According to the former, greater liquidity creation increases the risk of illiquidity for banks. Thus banks should strengthen their solvency because capital acts as a buffer against unexpected withdrawals from customers (Horvàth, Seidler, and Weill, 2014). In contrast, the "liquidity substitution" hypothesis (Distinguin et al., 2013) postulates that when banks face higher illiquidity they may consider certain liabilities as stable sources, thus substituting capital with those stable liabilities.

Berger and Bouwman (2009) empirically test the relationship between capital and a measure of liquidity creation for a sample of US banks over 1993-2003 with the expectation that the net effect

\footnotetext{
${ }^{3}$ The concept of bank liquidity refers to the ability of a bank to pay its obligations when they fall due; or, alternatively, the ability of institutions to make agreed upon payments in a timely fashion. In contrast, liquidity creation, entails the transformation of short-term funds in long-term (mostly illiquid) assets, thus raising liquidity risk.
} 
of bank capital on liquidity creation will likely differ depending on the banks' relative size. The authors find that the relationship is positive for large banks when the liquidity creation measure includes offbalance sheet items and insignificant when it is measured from on-balance sheet positions. For small banks, the relationship is negative and significant using both liquidity creation measures. More recently, Distinguin et al. (2013) employ a sample of US and European publicly traded banks over 2000-2006 and analyse the impact of bank liquidity, measured using on balance sheet items, on regulatory capital ratios. The results suggest that banks decrease their regulatory capital when they create more liquidity or when they face higher illiquidity as defined in Basel III. Thus, capital is negatively related to bank liquidity creation. However, the "financial fragility" hypothesis should depend on the deposit insurance coverage. If insurance were complete, depositors would not need to run on the bank in situations of uncertainty. Fungacova, Weill, and Zhou (2017) empirically examine whether the introduction of deposit insurance affects the relationship between capital and liquidity for an emerging market (Russia). They find that the presence of deposit insurance has only a limited impact on the negative relationship between capital and liquidity creation and this is mainly for banks characterised by relatively high household deposit ratios.

From an empirical point of view, the causal relationship between capital and liquidity is difficult to grasp because it may be jointly determined. Hovarth et al. (2012) analyse the possible bicausal relationship by employing a Granger causality test in a dynamic GMM panel estimator on a sample of Czech banks from 2000 to 2010. They show a negative relationship between capital and liquidity creation which confirms the financial fragility hypothesis. However, the authors also observe that liquidity creation Granger-causes a reduction in capital. This bi-directional negative causality suggests a trade-off between financial stability induced by stronger capital requirements and the economic benefits associated with liquidity creation.

Taking a different perspective, Vazquez et al. (2015) and Chiaramonte et al. (2017) investigate the evolution of bank liquidity and leverage and their implications for financial stability. Vazquez et al. (2015) show the complementary nature of liquidity and capital in explaining bank fragility. The authors also find evidence of differences across bank size. More precisely, the smaller the bank the more vulnerable to liquidity risk while large banks are more likely to fail due to insufficient capital buffers. On the other hand, Chiaramonte et al. (2017), by analysing a sample of banks headquartered in Europe, argue that capital and liquidity play a complementary role only for large banks, while for all banks the only significant determinant of bank failure is the Basel III structural liquidity ratio, which measures the mismatch in the bank balance sheet. The impact of regulatory intervention during crisis periods may also change the liquidity creation and risk-taking behaviour of banks. In a recent study on Germany, Berger, Bouwman, Kick, and Schaeck (2016) analyse the impact of regulatory interventions 
on bank liquidity creation. Using a dataset on 278 banks over 1999-2009, the authors find that regulatory interventions and capital support reduce both liquidity creation and bank risk-taking.

Based on the literature surveyed above, the issue of the relationship between capital and liquidity is far from unambiguous and is frequently found to be size-dependent. From a theoretical viewpoint, the "financial fragility/crowding out of deposits" hypothesis seems to apply more to small banks. Larger capital markets are often quite segmented implying that a shift in bank deposits have a relatively small impact on investors' demand for equity and deposits. Therefore, the relationship between capital and liquidity creation should be positive for large banks as empirically found in Berger et al. (2009). However, this result was found to be significant only for the definition of liquidity creation that accounted for off-balance sheet business. Other authors, namely Distinguin et al. (2013) and Hovarth et al. (2012) have recently argued that the relationship can be negative also for large banks. Possible reasons may derive from their too-big-to-fail positions and their priority access to safety nets that generate an underestimation of liquidity risk. Moreover, the decline in bank capital ratios arising from loan losses constrained banks to hold more liquid assets, hence reducing maturity transformation risk. It follows that a first hypothesis can be formulated as follows:

\section{H1: The relationship between capital and liquidity creation is negative for large European banks}

Our prediction is that the negative relationship between bank capital and liquidity will hold during the crisis years for all banks in our sample. We conjecture that the financial and the euro sovereign debt crises and the regulatory reforms that followed, induced European banks to consider liquidity and capital as complementary determinants. This implies that banks strengthened their capital when facing liquidity concerns. Vazquez et al. (2015) and Chiaramonte et al. (2017), for example, have recently demonstrated the complementary role of liquidity and capital in explaining bank fragility.

\subsection{The influence of liquidity risk and capital on CDS spread changes}

High bank leverage and structural mismatches in bank balance sheets are crucial factors in the propagation of the financial crisis. A follow-up question is: how are CDS spread changes, which reflect the market probability of failure, explained by the relationship between liquidity and capital? To derive a testable hypothesis for this question we rely on the literature explaining CDS spread determinants. 
The specifications of CDS spread models are based on the theory developed for the corporate bond credit spreads (Merton, 1974). However, structural variables have been found to have limited power in explaining credit spread changes. Recent studies (Collin-Dufresne, Goldstein, and Martin, 2001; Blanco Brennan, and Marsh, 2005; Ericsson, Kris, and Oviedo, 2009) extend structural models by including some additional factors such as stock market returns and the slope of the yield curve, in response to the so-called credit spread puzzle.

Works on CDS spread determinants (Galil, Shapir, Amiram, and Ben-Zion, 2014; Das, Hanouna, and Sarin, 2009; among others) generally exclude banks from the empirical investigations, due to their asset structure that exacerbates the credit spread puzzle. As a consequence, only a handful of studies shed light on the determinants of CDS spread changes in the banking sector. Annaert, De Ceuster, Van Roy, and Vespro, (2013) used structural variables to explain CDS spread changes for 32 listed euro area banks. They find that the determinants of CDS spread changes vary across time, so the models should be re-estimated frequently. The authors also highlight the importance of market liquidity and market-wide factors in addition to structural variables in explaining CDS spread changes.

Despite the popularity of market-based default metrics, the empirical literature on bank-failure (Cole and White, 2012; Berger, Imbierowicz, and Rauch, 2016; DeYoung and Torna, 2013; Altunbas, Manganelli, and Marques-Ibanez, 2017; among others) suggests that accounting information has an important role in predicting distress. If this is true, a hybrid model using both accounting ratios and market-based variables should better predict CDS spread changes. Hasan et al. (2015) investigate the effect of both structural variables and balance-sheet ratios on bank CDS spreads, while controlling for market factors. The authors find that balance-sheet ratios increase the explanatory power of structural variables. Furthermore, their results suggest that the impact of leverage and asset quality on CDS spreads is stronger during turmoil periods. Chiaramonte et al. (2013) find that CDS spreads reflect the credit risk captured by some balance sheet-ratios on a sample of European banks. In a related paper, Kanagaretnam et al. (2016) test the relevance of accounting information and loan/securities and investments by type in explaining CDS spread changes. The authors find that risky ABS securities and real estate were responsible for a major risk for US bank holding companies reflected in CDS spread changes. Liu et al. (2015) control for both structural variables and accounting indicators and find that deposit insurance has an adverse effect on bank CDS spreads. They also demonstrate that this tends to be greater when banks have poor asset quality and liquidity.

The studies discussed above demonstrate that leverage plays a pivotal role over the stability of banks, but largely ignore liquidity risk and off-balance sheet exposure. Although studies focused on CDS spread changes include proxies for liquidity, they mostly focus on either CAMEL-based asset side liquidity or the general funding liquidity. Maturity transformation risk is typically ignored, just as 
off-balance sheet exposures which are important determinants of banks' liquidity and leverage respectively. Furthermore, the joint relationship between liquidity risk and leverage is also ignored. Therefore, by taking in consideration these components we are able to extend the literature on banks' CDS spread determinants. Pairing these results with the findings of bank default studies, that show that capital and liquidity risk posed a serious threat to bank probability of failure (Chiaramonte et al., 2017; Vazquez et al., 2015), leads us to formulate the following hypothesis:

H2: The interplay between capital and liquidity contributes significantly to CDS spread changes

\section{Data and descriptive statistics}

\subsection{Data sources}

Our sample consists of European banks for which CDS contracts are listed. The selection of banking institutions is driven by the availability of data on CDS quotes on Bloomberg Professional Service. ${ }^{4}$ We obtain CDS spread series on 5-year senior debt contracts for 38 banks (a detailed list is provided in Table 1) at quarterly frequencies over the period 2005q1-2015q4. To ensure that CDS spread changes reflect meaningful information on bank credit risk, we retain only CDS spread changes during a given quarter if at least $80 \%$ of observations are non-zero during the quarter. Macroeconomic data are drawn from the World Bank's World Development Indicators (WDI) dataset. Table 2 shows the descriptive statistics of all the variables used in this study.

[Insert Table 1 about here]

[Insert Table 2 about here]

\subsection{Capital and liquidity risk proxy variables}

The target variables in our analysis are capital ratios and liquidity proxies as defined in Basel III. Capital requirements are usually set as a proportion of risk-weighted assets. The Basel II total regulatory capital ratio is defined as the sum of the core (Tier 1) and supplementary (Tier 2) capital on

\footnotetext{
${ }^{4}$ Bloomberg relies on Credit market analysis (CMA) for pricing credit derivatives. CMA receives quotes for credit instruments from 30 buy-side firms, including major investment banks, hedge funds and asset managers.
} 
risk-weighted assets. This latter includes hybrid instruments, therefore in order to gain a deeper insight we consider the total common equity tier 1 (CET 1), which is the ratio of total shareholder funds on risk-weighted assets. However, the risk-weighted calculation under Basel II rules might not reflect the actual risk. Capital measures based on non-risk-weighted assets may have been considered as more meaningful for stock participants (Demirgüç-Kunt, Detragiache, and Merrouche, 2013a) and better predictors of bank failure. In line with these studies and with the new Basel III regulations, we test the banks' common leverage ratio as measured by the ratio of equity to total assets. Since large banks might increase their risk exposure through the management of their off-balance sheet activities, we also consider another measure of leverage defined as the ratio of equity to total assets and off-balance sheet exposures, in line with Basel III's provisions. Regulatory capital formulations refer to measures of capital at book value, however banks could base their liquidity risk management practices also on market measures of capital. For example, banks might target a market value of capital below which the bond market starts charging a risk premium; or they might target both book and market value of equity needed to pursue future acquisition strategies. Therefore, we also include the ratio of market capitalization to total market value.

The banking literature has developed several synthetic liquidity indicators that attempt to gauge the true liquidity position of a bank (Deep and Schaefer, 2004; Berger et al., 2009; BIS, 2009). In the liquidity creation measure developed by Berger et al. (2009) assets and liabilities are classified as liquid, semiliquid or illiquid according to their maturity and weighted accordingly. The authors assume that liquid assets are easier to sell than illiquid assets and liquid liabilities can be more quickly withdrawn without penalty. Higher value of liquidity creation indicate higher bank illiquidity as bank invest liquid liabilities into illiquid assets. In that case, the bank is more exposed to maturity transformation risk if costumers claim the higher liquid portion of liabilities invested in illiquid assets saleable at fire sale prices. The liquidity creation measure is closely related to the regulatory measure of funding stability. The latter measure aims to promote bank resiliency by creating incentives for banks to fund their activities with more stable sources of funding. This liquidity measure is the ratio of the available stable funding (i.e. capital, liabilities with maturities of one year or greater, stable deposits) to the required amount of stable funding (i.e. the amount of assets with longer maturities). Higher values indicate lower illiquidity, as the bank is less involved in maturity transformation activities. Based on their characteristics, we can argue that both indicators try to capture maturity transformation risk and both are measured giving a weight of the balance sheet items depending on their stability.

In this study, we measure liquidity in a way consistent with Basel III's provisions, and employ the NSFR, defined as the ratio of available stable funding to required stable funding. More precisely, 
the NSFR is a ratio between the weighted sum of the different type of liabilities $\left(\mathrm{L}_{\mathrm{i}}\right)$ and assets $\left(\mathrm{A}_{\mathrm{J}}\right)$ as shown in equation (1).

$$
N S F R=\frac{\sum_{i} w_{i} L_{i}}{\sum_{j} w_{j} A_{j}}
$$

The weights $w_{i}$ are defined by the Basel Committee and reflect the stability of the balance sheet components. It is to note that the lower is the NSFR, the higher is the bank liquidity risk but the higher is also the liquidity creation. Vice versa, the higher the NSFR, the lower the liquidity risk and the lower the liquidity creation, as banks produce less illiquid assets (i.e. loans).

The details of all capital and liquidity proxy variables employed in this study are provided in Table 3.

[Insert Table 3 about here]

We test five measures of capital and two of liquidity. The proxies for capital include two risk unweighted capital ratios (with and without off-balance sheet exposures), two risk-weighted ones (total CET1 and total regulatory capital) and market capital, that is the ratio of equity market value to total market value of assets. Concerning liquidity, in 2014 the Committee issued a revision of the weights of the NSFR previously defined in the 2010 version. Due to the evolving nature of the Basel III, we calculate the two versions of the NSFR: NSFR_14 based on the latest technical document (BCBS, 2014); and NSFR_10, based on the original document (BCBS, 2010b). ${ }^{5}$ We expect that using alternative definitions of capital and liquidity not only will add robustness to our results but also in some cases produce different results. Notably, we predict risk-based capital ratios to be less able to capture the simultaneous interrelations between capital and liquidity; we also expect market leverage to behave differently as market variations of equity are directly reflected on the marked-to-market leverage.

\footnotetext{
${ }^{5}$ It should be noted that these measures are approximations because the granularity of bank assets and liabilities needed to calculate the NSFR is not available in Bloomberg professional service. As a result, we cannot split the loan portfolios according to their maturity and types, which under Basel III entails different weights. Following a conservative approach, we fix that the portfolio of loans requires an overall weight of 0.85 . Furthermore, we cannot split securities in government bonds and other securities. Thus, following a conservative approach, we use a weight of 0.5 , which is within the weight brackets proposed in Basel III for other securities items. This is in line with e.g. Distinguin et al. (2013) and Chiaramonte and Casu (2017).
} 


\section{Empirical methodology}

\subsection{Modelling the relationship between liquidity risk and capital}

We first analyse the relationship between liquidity and capital using the set of proxy variables defined in Section 3.2. This analysis investigates the contribution of liquidity in explaining bank capital ratios. Berger et al. (2009) and Distinguin et al. (2013) claim that bank capital might also be a determinant of bank liquidity creation. For example, requiring a bank to hold more high-quality liquid assets makes it safer and less dependent on capital. To deal with simultaneity that is associated with endogeneity bias, we use a simultaneous equations model as in Distinguin et al. (2013).

In the first equation in the system specified in (2), we regress capital ratios on a set of bankspecific and macroeconomic factors, to which we add liquidity measures. In the second equation, we regress liquidity measures on a set of independent variables that include: bank-specific factors, the macroeconomic environment and the European Central Bank (ECB) policies. We employ a simultaneous equations model, where the system of equations is estimated via GMM:

$$
\left\{\begin{array}{c}
\text { Capital }_{i, t}=\alpha_{i, t}+\beta \text { Liquidity }_{i, t}+\sum_{k=1}^{K} \varphi_{k} D C_{k i, t-1}+\sum_{j=1}^{J} \varphi_{j}^{\prime} D C_{j i, t-1}+\varepsilon_{i, t} \\
\text { Liquidity }_{i, t}=\partial_{i, t}+\delta \text { Capital }_{i, t}+\sum_{m=1}^{M} \gamma_{m} D L_{m i, t-1}+\sum_{n=1}^{N} \gamma_{j}^{\prime} D L_{n i, t-1}+\vartheta_{i, t}
\end{array}\right.
$$

Capital and Liquidity correspond to the capital and liquidity proxies, respectively. $D C_{k i, t}$ and $D L_{m i, t}$ are the $k^{\text {th }}$ and the $m^{\text {th }}$ exogenous determinants of capital and liquidity. $D C_{j i, t}$ and $D L_{n i, t}$ are the $m^{\text {th }}$ and the $n^{\text {th }}$ endogenous determinants of capital and liquidity. The equations of the system described in (2) are estimated simultaneously through a GMM approach.

A challenge for the estimation of our simultaneous equations system relates to potential endogeneity problems. For example, banks with a higher capital ratio tend to have higher NSFR as equity enters in the NSFR calculation. However, causation could also run in the opposite direction, when banks choose a higher NSFR in times of crisis, which in turn affects the levels of capital held. Following recent empirical studies, including Distinguin et al. (2013) and Dietrich et al. (2014), we test the endogeneity of the independent variables for both equations using the Durbin score and the 
Wu-Hausman test to identify the appropriate instrument matrix. Endogenous covariates have been instrumented by their one-quarter lagged values. ${ }^{6}$

We estimate the simultaneous equation through the GMM estimation method using robust standard errors. Following the relevant literature, in the capital equation in (2), we control for profitability, asset risk, bank charter value, size and the macroeconomic environment. We include profitability (the standard return on equity) because raising additional capital is costly. According to the pecking order theory funding extra capital is the most expensive financing choice, hence it may be easier to increase capital through retained earnings and lower dividend payments (Flannery and Rangan, 2008). Increasing capital buffers is relatively easy when earnings are high, thus we expect a positive relation between profitability and capital ratios. Asset risk is also included in the capital equation. According to Jokipii and Milne (2008), Berger, De Young, Flannery, Lee, and Öztekin (2008), and Flannery et al. (2008) banks with risky portfolios generally hold more capital. This is because bank capital can be viewed as a buffer for absorbing losses from risky assets. During the crisis, the provisions for bad loans were not sufficient to absorb all losses. Thus banks had to increase the level of their allowances as a consequence of the accumulation of credit risk, which came at the expense of bank profits and ultimately impacted bank capital. Therefore, we expect a negative sign for the coefficient of the loan loss provisions over total assets in the determination of bank capital due to the unexpected cost of risk. Banks with higher chartered values might raise capital more easily and cheaply than their peers, implying less need for capital buffers (Berger et al., 2008).

In contrast, Gropp and Heider (2010) suggest that bank reputation and chartered value should be protected by larger capital buffers. We use the ratio of market to book value as an indicator of chartered value. We have no expectations regarding the sign of the coefficient of this variable in the capital regression. Bank size is included to capture size effects on bank capital ratios. According to Berger et al. (2008), large banks are inclined to hold relatively lower capital buffers since they tend to be more diversified and better able to manage their risky assets. On the contrary, large institutions are constrained to hold more capital due to their systemic relevance, hence the relationship could be negative. We use the logarithm of total assets as a proxy of bank size. We do not have a prediction for the sign of the coefficient of this variable in the capital regression. Capital buffers are also related to the economic cycle. Capital requirements are procyclical because they may intensify the fluctuations of the business cycle, but large banks typically maintain significant capital surpluses (capital in excess

\footnotetext{
${ }^{6}$ In the capital equation the endogenous variables are: NSFR, ROE and the loan loss provision, while in the liquidity equation the endogenous variables is: capital. We instrumented endogenous covariates by their one quarter lags. Using lagged variables as instruments is a common approach in the banking literature. A similar methodology is also applied in Dietrich et al. (2014) and Distinguin et al. (2013) for investigating the relationship between liquidity and performance and liquidity and capital, respectively.
} 
of the capital requirements). The behaviour of these buffers may be countercyclical if banks use expansionary macroeconomic periods to rebuild capital during upturns. On the contrary, during recessions defaults on bank loans increase and generate higher losses that might impair buffers of capital. Therefore, we include the growth of real gross domestic product (GDP) as a proxy of the business cycle and although we expect a negative sign for GDP growth, we do not exclude the possibility of a positive relationship depending on the definition of capital used.

In the liquidity equation in (2), we include the following variables: size, structural funding risk, central bank net lending facilities and, as for the capital equation, the macro environment. As noted above (Section 2.1), size differences among banks are expected to affect the degree of liquidity creation (Berger and Bouwman, 2009). Moreover, size could be an indicator of market power, which improves the ability of banks to create liquidity from their balance sheet exposures. We expect a negative sign for the coefficient of this variable (proxied by the natural log of total assets) in the determination of bank liquidity. Following Hackethal, Rauch, Steffen, and Tyrell (2010) and Distinguin et al. (2013) when central bank's policy rates decline credit supply to financial institutions increases, which positively affect bank liquidity. To uncover this effect, we use the ECB net lending to credit institutions index. ${ }^{7}$ We expect a positive sign for the coefficient of this variable in the determination of bank liquidity.

In line with Distinguin et al. (2013), we introduce a proxy variable for liquidity pressure in the interbank market. We consider the spread between the one-month interbank rate and the policy rates and we expect that higher values of this variable will positively affect bank liquidity. The macroeconomic control variable for bank liquidity is based on Dietrich et al. (2014). In particular, we include the growth of real GDP and we expect a negative sign, as during economic booms banks increase liquidity creation (Distinguin et al., 2013).

Finally, we include the logarithm of CDS changes to control for potential changes in the management of liquidity risk and capital in times of market stress. Before the crisis, potential threats related to liquidity and capital were widely ignored and banks were incentivised to rely on short-term funding rather than more stable funding sources. After the crisis, lack of liquidity and capital forced them to shrink their balance sheets, which would have had a beneficial effect on capital and NSFR.

\footnotetext{
${ }^{7}$ The index measures the net lending to credit institutions. For further descriptions see: "TLCIECB Index" on Bloomberg Professional Service.
} 


\subsection{Factor model CDS spreads}

To examine the importance of the relationship between liquidity risk and capital, we ask whether both risks affect credit spread changes. To do so, we run a panel data fixed-effect regression model. Each regression uses the logarithm of quarterly CDS spreads as a dependent variable. Independent variables include bank structural variables, CAMELS indicators and macroeconomic controls. The baseline model is as follows:

$$
C D S_{i, t}=\alpha+\beta \text { Capital }_{i, t}+\gamma \text { Liquidity }_{i, t}+\delta Y_{i, t}+\lambda Z_{j, t}+\vartheta_{t}+\varepsilon_{i, t}
$$

where $C D S$ is the natural logarithm of CDS spread for bank $i$ at year $t$; Capital and Liquidity are the five definitions of capital and the two measures of the NSFR described in Table 3. $Y$ represent a set of bank specific covariates. $Z$ represents structural variables and country level controls. $\vartheta_{t}$ are time fixed effects. We perform several tests to choose the appropriate method to estimate equation (3). The Hausman test and the Breusch-Pagan LM test recommend the use of a random effects (RE) model. The modified Wald test indicates the presence of heteroscedasticity. As a consequence, we estimate equation (3) using the RE estimation method and the Huber-White sandwich estimator to obtain standard errors that are robust to cross-sectional heteroscedasticity and within panel correlation.

Following Kanagaretnam et al. (2016), Hasan et al. (2015), Chiaramonte et al. (2013), we include in the model these variables: the ratio of non-performing loans to total loans as a measure of asset quality; the return on assets as a measure of performance; the interest income over total income to control for traditional banking activities; and (the natural log of) total assets as a proxy for size. We also control for structural variables and market-wide factors. In particular, for asset volatility we use the 60 days' historical standard deviation of banks' daily equity returns in a particular quarter (see Ericsson et al., 2009; Campbell and Taksler, 2003; and Galil et al., 2014). To reduce the credit-spread puzzle we include two market-wide factors following, among others, Ericsson et al. (2009), CollinDrufesne et al. (2001), Annaert et al. (2013) and Campbell et al. (2003). These are: the difference between the 10-year redemption yields and the 1-year Euribor rate that allows us to control for the market expectation about future conditions in the financial markets; and the return of the Eurostoxx 600 stock index as a proxy of general business climate improvements. 


\section{Empirical results}

\subsection{The relationship between capital and liquidity}

Tables 4 and 5 report the results of the simultaneous equations system described in equation (2). Our findings in Table 4 indicate that there is a positive bidirectional relationship between the capital ratios defined in the Basel III regulatory framework and the equity to total assets ratio and the NSFR. The higher the NSFR (the higher the liquidity of a bank) the higher the plain capital ratios. This evidence supports the "financial fragility/crowding out of deposits" hypothesis according to which higher capital hampers liquidity creation. This can occur either because of less monitoring, as theorised in Diamond et al. (2000; 2001), or because investors' funds are shifted from deposits to capital thus reducing overall liquidity (Gorton et al., 2010, 2017). However, as noted in Berger and Bowman (2009) the effect is likely to be less important for large banks as these have easy access to domestic and international financial markets. ${ }^{8}$

The bidirectional relationship appears stronger, in columns (1a)-(1b) where we take into account the off-balance sheet exposures in the leverage ratio. This implies that large banks manage liquidity risk with sophisticated strategies that involve off-balance sheet exposures. Therefore the simple ratio of equity to total assets is less useful in understanding the relationship between capital and liquidity when examining large institutions.

\section{[Insert Table 4 about here] \\ [Insert Table 5 about here]}

In Table 5, we analyse the relationship between liquidity and capital with risk-based and market- based measures of capital. We find that the NSFR is positive and significant when the Basel II risk-based capital ratios are the dependent variables. These results are in line with e.g., Distinguin et al. (2013), who claim that instead of strengthening their solvency standards, banks reduce their regulatory ratios when they face higher funding liquidity risk. Another explanation is that banks that have too much liquidity risk are unable to raise additional capital because they are considered too risky by investors.

\footnotetext{
${ }^{8}$ The role of capital in liquidity creation may also be weakened by the provision of a depositors' protection scheme. Using a natural experiment for the Russian banking sector, Fungacova et al. (2017) find that for those banks characterised by relatively high household deposit ratios, the introduction of the deposit insurance in 2004 affects the relationship between capital and liquidity creation. Although not tested in this study due to data limitations, one should not ignore that the relationship between capital and liquidity creation may be weakened by the provision of a depositors' protection scheme. We thank an anonymous referee for noting this point.
} 
In columns (5a) and (5b) we consider the market-based capital measure. We focus on market leverage because we are interested in the immediate impact of equity reductions on the NSFR, as market leverage reflects investors' responses to market developments. When capital is marked to market, the responses to equity price changes are directly reflected to the market-based capital measure and may be disproportionately large in certain periods. According to Adrian and Shin (2010; 2014) marked-to-market leverage is strongly procyclical - that is, market variations of equity are directly reflected on the marked-to-market leverage - this may entail an immediate impact on the NSFR as capital decreases instantaneously, thus we find a negative and significant coefficient of the NSFR in the capital equation. Although capital decreases instantaneously due to market forces, banks then readjust their balance sheets through capital injections and asset substitution strategies, and this is evidenced by the positive coefficients displayed in columns 1a to $4 \mathrm{~b}$.

Most of the findings are consistent with our predictions and those obtained in previous studies. In the capital equation, credit risk variables are always negative and significant, suggesting that banks strengthen their capital ratios when they face higher credit risk. The logarithm of total assets has a negative sign when we adopt the unweighted and the market measures of capital, while the relationship is positive when we use risk-weighted definitions of capital. This mixed result could be related to banks' business mix, which has an impact on the estimation of the risk-weighted assets (i.e. loans have a higher charge in terms of risk-weighted assets compared to market based activities). We also find a negative and significant relationship between regulatory capital ratios (column 3a to 4b) and the GDP growth variable, while the other definitions of capital are positively related with the GDP growth variable. ROE is usually positive and carries a negative and significant sign when total regulatory capital is the dependent variable. This can be explained by the fact that the denominator (RWA) increases if banks engage in riskier activities (such as corporate loans) which are typically more profitable than less risky ones (securities).

The control variables in the liquidity equation are all statistically significant and with the expected signs. In contrast to the literature that covers the period before the global financial crisis (Berger et al., 2009; Distinguin et al., 2013), we find a positive association between size and liquidity, while GDP growth is no longer significant. As expected, the coefficients of the interbank spread variable is positive and significant, suggesting that shocks in the interbank market force banks to increase their liquidity holdings. Moreover, the ECB liquidity injections increases bank liquidity during stressed market periods.

Finally, we find a positive and significant sign for the lagged CDS spread variable in both the capital and liquidity equations. The results support our hypothesis that during stressed market periods, banks try to increase liquidity and capital to overcome financial market turmoil. 


\subsection{The impact of liquidity and capital on CDS spread changes}

To examine the importance of liquidity risk and capital, we ask whether both risks affect credit spread changes. The meaningful relationship between those variables discussed in Section 4 indicates a joint management of liquidity and capital in banks. If this is true we should find that capital and liquidity risk contribute to CDS spread changes, as predicted by our second hypothesis H2.

Table 6 reports the results from running equation (3) in ten different models, using the five capital definitions and both versions of the NSFR. More precisely, we run the regression with Basel III formulations of capital (models 1a to $2 \mathrm{~b}$ ), the Basel II risk-based measures of capital (models 3a$4 b)$, and the market-based measures of capital (5a-5b).

\section{[Insert Table 6 about here]}

In most of the cases, the estimated coefficients for capital when significant are negative. This suggests that capitalised banks are perceived as safer than their less capitalised counterparts. The liquidity proxy variables are positive and insignificant in all regression models, suggesting that funding liquidity risk is not a determinant of CDS spread changes for large European banks. However, the lack of significance of the variable could be explained in different ways. Banks with higher credit risk might reduce maturity mismatches in order to reduce the probability of default (Imbierowicz et al., 2014). In addition, during the crisis banks with ratios of NSFR close to the minimum regulatory target might have decreased lending to manage liquidity risk. ${ }^{9}$ To shed further light into the matter, in Section 6.2 we include a dummy variable to analyse if values of NSFR below one is a priced risk factor. We also analyse if liquidity ratios below the minimum requirement affect CDS spread changes through their interaction with capital measures.

Table 6 also shows a positive relationship between bank CDS spreads and asset quality and a negative one with performance. The signs of these two variables reveal that the probability of default tends to increase with poor-quality loan portfolio and/or lower returns on assets. These outcomes confirm the findings of Chiaramonte et al. (2013) and Hasan et al. (2015). The share of interest income over total income appears to increase CDS spreads. The sign of the coefficient is in line with Demirgüç-Kunt et al. (2013b) who highlighted that fee income is negatively related to CDS spreads. However, this finding is in contrast with the literature on bank failure: DeYoung et al. (2013)

\footnotetext{
${ }^{9}$ We test the proposition in the robustness test section.
} 
demonstrate that banks with a higher level of fee-income are more likely to fail. In terms of asset size, the sign is negative and significant at the $1 \%$ level suggesting that the largest banks are considered less risky by the markets. This could be driven by the fact that these institutions are systemically important, or even TBTF (Too Big To Fail), and therefore more likely to benefit from government safety net guarantees.

The equity volatility variable has coefficients consistent with theory (Merton, 1974) and statistically significant at the $5 \%$ level. As for the market-wide variables, the Eurostoxx and the term spread variables are both statistically significant and have the expected signs. In particular, the performance of the Eurostoxx has a negative sign, indicating that a deterioration in general business climate increases the probability of default and recovery rates, thus increasing CDS spread. In contrast, the term spread has a positive and significant sign. This is related to the increase in peripheral European government 10-year yields during the sovereign crisis, which obviously affected sovereign and bank CDS spreads.

\subsubsection{Are threshold effects at play?}

While all banks in our sample meet the minimum required capital target, some do not meet the liquidity requirements, while others have a NSFR well above the minimum required. To gauge potential threshold effects, we add a dummy variable to equation (3) which takes value one in case of the NSFR is below the minimum required and zero otherwise. The results of the investigation are reported in Table 7.

\section{[Insert Table 7 about here]}

In all cases when significant, we find a positive sign for the NSFR. This could be explained by the fact that banks with higher credit risk reduce lending to keep liquidity risk low to maintain the total level of default risk limited. ${ }^{10}$ On the contrary, banks with low credit risk do not necessarily have to manage both risks jointly because the overall risk is limited (Imbierowicz et al., 2014). Although the NSFR provision became a minimum standard by January $1^{\text {st }}, 2018$, the positive and significant sign of the dummy variable in all regression results suggests that the credit derivatives' market prices the risk of having higher liquidity mismatches.

\footnotetext{
${ }^{10}$ The correlation matrix shows a positive correlation between the NSFR and the ratio of NPLs to total loans, confirming our interpretation of the sign of the coefficient. In the robustness section, we demonstrate the proposition with an ad hoc regression model.
} 


\subsubsection{Model with indirect effects of liquidity risk}

In this subsection, we assume that liquidity ratios below the minimum requirement affect CDS spread changes through their interaction with capital measures. Table 8 reports the results for models with indirect effects of liquidity risk. Specifications (1a) to (5b) include an interaction term between the capital ratio and the dummy variable $\left(C a{ }^{*} N S F R\right)$ that takes value 1 if the NSFR is below one and 0 otherwise.

In all cases, when significant the interaction terms are positive, thus indicating that financial markets consider banks that have a higher liquidity risk $(\mathrm{NSFR}<1)$ riskier independently of their level of capital. The coefficients of the control variables remain roughly similar in terms of magnitude and significance, confirming the findings of the previous regression models.

[Insert Table 8 about here]

Overall these results show that the interaction between capital and liquidity affects the probability of failure when liquidity is below the minimum regulatory target. Moreover, they could suggest that banks that have too much liquidity risk are expected to have difficulties in raising potentially further capital because they are perceived as too risky by investors. This implies that risky funding structures can lead to higher probability of default irrespective of capital levels. Requirements of funding liquidity in conjunction with capital requirements could thus help prevent the increase in probability of defaults of large financial institutions that could trigger systemic risk to the entire financial sector.

The significance and magnitude of the control variables generally confirm the findings of the previous regression models reported in Tables 4-5.

\section{Robustness tests}

\subsection{Robustness: bank capital and liquidity}

To test the reliability of our results on the relationship between bank capital and liquidity, we perform a battery of robustness checks. First, since the loan loss provision could be a discretionary tool to smooth earnings over time (Leventis, Dimitropoulos, and Anandarajan, 2011), we re-estimate 
the simultaneous equations system using an alternative credit risk measure. Specifically, we rely on the ratio of loan loss reserve to non-performing loans as a proxy of resources set aside to cover expected credit losses. The idea is that, if an institution lacks sufficient loan loss reserves to cover loans chargedoff, the excess charge-offs will be covered with capital. The results of the main variables of interest, reported in Table 9, are consistent with those previously obtained with the loan loss provision to total assets.

[Insert Table 9 about here]

We also consider two alternative liquidity proxies: the "liquidity transformation gap" (LT gap) defined in Deep and Schaefer (2004) and the cat-fat liquidity creation measure proposed by Berger et al. (2009). The LT gap is the difference between liquid liabilities and liquid assets held by a bank divided by its total assets. Thus the higher the coefficient the higher the illiquidity of a bank. The "catfat" liquidity creation indicator assigns weights to different assets and liabilities based on their liquidity as defined in Berger et al. (2009). Similarly, to the liquidity transformation gap the higher the coefficient the higher the illiquidity of a bank. Again, our checks (Table 10) are consistent with those previously obtained with the NSFR variables in Tables 4 and 5.

[Insert Table 10 about here]

Finally, according to Dietrich et al. (2014) business models may also have an impact on the NSFR. Given the higher weights assigned to loans and deposits in the denominator and numerator of the NSFR respectively, financial institutions focused on the lending/deposit taking business might have a higher NSFR than banks with a higher proportion of investment banking activities. We control for business models by adding the ratio of interest income to total income in the liquidity regression. The results (Table 11) are consistent with those obtained previously. Moreover, the interest income to total income variable has a positive and significant sign in line with the findings of Dietrich et al. (2014).

[Insert Table 11 about here] 


\subsection{Robustness: CDS spread changes}

Several possible explanations are consistent with the positive relationship between the NSFR and CDS price changes. During the crisis banks with higher credit risk might reduce lending to keep liquidity risk low to maintain the total level of default risk limited. Moreover, banks with higher illiquid assets on their balance sheet might have reduced lending to increase asset liquidity. To test these hypotheses, we estimate a panel data fixed effect model where we regress the NSFR on five key drivers of liquidity risk management: (1) the level of non-performing loans; (2) the loan growth variable; (3) deposits as a fraction of total funding; (4) the Basel III leverage ratio; and (5) bank asset size. We include this latter to proxy for additional sources of heterogeneity among banks.

To gauge the effects of the crisis we interact the variables with the interbank pressure, defined as the spread between the one-month interbank rate and the policy rates. We also control for time fixed effect with quarterly time dummies. The selection of the variables used is based on Cornett, McNutt, Strahan, and Tehranian (2011). Table 12 reports the regression results. We find evidence to support our hypotheses. Banks with higher credit risk tend to increase liquid assets to maintain the overall risk limited. In contrast, banks with higher NSFR ratios and lower credit risk continue to lend during the crisis period.

[Insert Table 12 about here]

To further check the validity of our results, we conduct a series of diagnostic tests. First, a potential concern may be the presence of endogeneity in our specification. As suggested in Volz et al. (2011), potentially our control variables for leverage, liquidity and credit risk may be determined simultaneously with CDS spreads. To deal with this issue, we estimate equation (3) through a random effects instrumental variable approach (IV-RE) and instrumented leverage, NSFR and the NPL ratio using their own lagged values. Results of the estimation are reported in Table 13. Clearly the concern of endogeneity appears limited and does not impact our variables of interest: leverage and liquidity risk. With the IV-RE approach credit risk increases in significance and performance variable decreases in significance, the other control variables remain roughly the same. We check also the results of the model with threshold effects with a different configuration. Specifically, we apply the IV-RE approach and instrumented leverage, the dummy variables which takes the value one in case the NSFR is below one (NSFR_10 $<1$ or NSFR_14 $<1$ ) and the credit risk variable with their own lags. The results of the estimation reported in Table 14 remain roughly the same as those shown in Table 7 with the RE model. As a third robustness check, we estimate equation (3) with a random effect GLS estimator 
under the assumption that the disturbance term is first-order autoregressive derived by Baltagi and Wu (1999). Results in Table 15 confirm the main results reported in Table 6.

Finally, we perform collinearity checks and correlation analysis among explanatory variables and do not find multicollinearity problems for all the regression reported. ${ }^{11}$

[Insert Table 13 about here]

[Insert Table 14 about here]

[Insert Table 15 about here]

\section{Conclusions}

Capital and liquidity are two crucial factors for bank survival. This study investigates the interconnections between these factors and the impact on CDS spreads for a sample of European banks over 2005 to 2015. Using various configurations of capital and liquidity consistent with the new Basel III regulation, we find a bidirectional positive relationship between capital and funding liquidity risk. The results also point to the need to appropriately measure capital and liquidity proxies. More precisely, we highlight the importance of considering off-balance sheet exposures in understanding the connections between capital and liquidity.

Overall, our evidence supports the financial fragility hypothesis developed in Diamond et al. (2000; 2001) and are consistent with the empirical findings of e.g. Distinguin et al. (2013) and Horvàth et al. (2014). Given the complex relationship between capital and liquidity and the importance of both factors for financial stability, we question whether these are priced risk factors in the CDS market. We find that capital is a significant determinant of CDS spread changes, while the NSFR becomes significant only when the ratio falls below the minimum regulatory threshold. We also document that the interactions of both variables significantly determine banks' market probability of default.

This study offers several interesting policy implications. Our findings support the current set of regulatory reforms that introduced new minimum liquidity requirements concomitant to stricter capital ratios, as both are closely related to each other. Capital and liquidity requirements can thus help prevent the occurrence of systemic effects of risky funding sources as the last crisis has vividly

\footnotetext{
${ }^{11}$ For brevity, these results are not presented in the text, but they are available from the authors upon request.
} 
demonstrated. Furthermore, in this study we observe that if the new multi-polar approach to bank regulation is desirable, the evidence of a bidirectional relationship between capital and liquidity calls for the introduction of interacting regulatory instruments i.e. a regulatory approach that accounts for such interconnections. Our results also cast doubts on the accuracy of risk-based capital ratios in capturing the simultaneous interrelations between capital and liquidity. This may need to be reassessed in a few years' time as banks will have adapted to the Basel III reforms recently introduced by the Basel Committee (BCBS, 2017) to restore the credibility of the risk-based capital framework.

In addition, our work provides evidence of market discipline in CDS spreads, as demonstrated by the positive correlation between bank risk and banks' market probability of default. The derivative market evaluates changes in leverage and funding liquidity risk and incorporates those factors promptly into banks' CDS spreads. Therefore, monitoring such securities generates signals that may convey useful information to supervisors to detect potential balance sheet weaknesses of large banks that could prompt systemic risk to the entire financial system. We noticed also that excessive maturity transformation is priced on CDS spreads and has an increasing effect on market probability of default. Finally, although not tested due to data limitations, the role of capital in liquidity creation may be weakened by the provision of depositors' protection schemes. This will become even more important in the near future as the completion of the Banking Union with the European Deposit Insurance Scheme (EDIS) will call for further research on the relationship between capital and liquidity and the subsequent impact on banks' probability of default. In particular, the introduction of the EDIS will likely to change the relationship between capital and liquidity for banks based in countries with lower protection of deposits. For these banks the deposit insurance scheme will likely weaken the impact of capital on liquidity creation. 


\section{References}

Adrian, T., Shin, H. S. (2014). Procyclical leverage and value-at-risk. Review of Financial Studies. 27 (2), 373-403.

Allen, F., Gale, D. (2004). Financial Intermediaries and Markets. Econometrica, 72(4), 1023-1061.

Altunbas, Y., Manganelli, S., Marques-Ibanez, D. (2017). Realized bank risk during the great recession. Journal of Financial Intermediation, 32, 29-44.

Annaert, J., De Ceuster, M., Van Roy, P., Vespro, C. (2013). What Determines Euro are Bank CDS Spreads?. Journal of International Money and Finance, 32, 444-461.

Baltagi, B.H., Wu, P.X. (1999). Unequally spaced data regressions with AR(1) disturbances. Econometric Theory, 15, 814-823.

Basel Committee on Banking Supervision (BCBS). (2010a). Basel III: A Global Regulatory Framework for More Resilient Banks and Banking Systems (revised June 2011).

Basel Committee on Banking Supervision (BCBS). (2010b). Basel III: International Framework for Liquidity Risk Measurement, Standards and Monitoring (December).

Basel Committee on Banking Supervision (BCBS). (2014). Basel III: The Net Stable Funding Ratio (October).

Basel Committee on Banking Supervision (BCBS). (2017). Basel III: Finalising Post-Crisis Reforms (December).

Bhattacharya, S., Thakor A. V. (1993). Contemporary Banking Theory. Journal of Financial Intermediation, 3(1), 2-50.

Berger, A. N., Bouwman, C. H. S. (2009). Bank Liquidity Creation. Review of Financial Studies, 22(9), 3779-3837.

Berger, A. N., De Young, R. Flannery, M. J., Lee, D., Öztekin, Ö. (2008). How Do Large Banking Organizations Manage Their Capital Ratios?. Journal of Financial Service Research, 34(2-3), 123-149.

Berger, A. N., Imbierowicz, B., Rauch, C. (2016). The Roles of Corporate Governance in Bank Failures during the Recent Financial Crisis. Journal of Money, Credit and Banking, 48(4), 729770.

Berger, A. N., Bouwman, C. H. S., Kick, T., Schaeck, K. (2016). Bank liquidity creation following regulatory interventions and capital support. Journal of Financial Intermediation, 26, 115-141.

Blanco, R., Brennan, S., Marsh, W. (2005). An Empirical Analysis of the Dynamic relation between Investment-Grade Bonds and Credit Default Swaps. Journal of Finance, 60(5), 2255-2281.

Campbell, J. Y., Taksler, G. B. (2003). Equity Volatility and Corporate Bond Yields. Journal of Finance, 58(6), 2321-2281. 
Chiaramonte, L., Casu, B. (2013). The Determinants of Bank CDS Spreads: Evidence from the Financial Crisis. The European Journal of Finance, 19(9), 861-887.

Chiaramonte, L., Casu, B. (2017). Capital and Liquidity Ratios and Financial Distress. Evidence from the European Banking Industry. The British Accounting Review, 49(2), 138-161.

Cole, R. A., White, L. J. (2012). Déjà vu All Over Again: The Causes of US Commercial Bank Failures This Time Around. Journal of Financial Services Research, 42(1-2), 5-29.

Collin-Dufresne, P., Goldstein, R. S., Martin S. J. (2001). The Determinants of Credit Spread Changes. The Journal of Finance, 56(6), 2177-2207.

Cornett, M. M., McNutt, J. J., Strahan P. E., Tehranian, H. (2011). Liquidity Risk Management and Credit Supply in the Financial Crisis. Journal of Financial Economics, 101(2), 297-312.

Das, S. R., Hanouna, P., Sarin, A. (2009). Accounting-Based Versus Market-Based Cross-Sectional Models of CDS Spreads. Journal of Banking \& Finance, 33(4), 719-730.

Deep, A., Schaefer, G. (2004). Are Banks Liquidity Transformers? (KSG Working Paper No. RWP04022). Available on the internet at https://ssrn.com/abstract=556289.

Demirgüç-Kunt, A., Detragiache, E., Merrouche, O. (2013a). Bank Capital: Lessons from the Financial Crisis. Journal of Money, Credit and Banking, 45(6), 1147-1164.

Demirgüç-Kunt, A., Huizinga, H. (2013b). Are Banks Too Big To Fail or Too Big To Save? International Evidence From Equity Prices and CDS Spreads. Journal of Banking \& Finance, 37(3), 875-894.

DeYoung, R., Torna, G. (2013). Nontraditional Banking Activities and Bank Failures During the Financial Crisis. Journal of Financial Intermediation, 22(3), 397-421.

Diamond, D. W., Dybvig, P. H. (1983). Bank runs, deposit insurance, and liquidity. Journal of Political Economy, 91(3), 401-419.

Diamond, D. W., Rajan, R. G. (2000). A Theory of Bank Capital. Journal of Finance, 55(6), 24312465.

Diamond, D. W., Rajan, R. G. (2001). Liquidity Risk, Liquidity Creation and Financial Fragility: A Theory of Banking. Journal of Political Economy, 109(2), 287-327.

Dietrich, A., Hess, K., Wanzenried, G. (2014). The Good and Bad News About the New Liquidity Rules of Basel III in Western European Countries. Journal of Banking \& Finance, 44, 13-25.

Distinguin, I., Roulet, C., Tarazi, A. (2013). Bank Regulatory Capital and Liquidity: Evidence from US and European Publicly Traded Banks. Journal of Banking and Finance, 37(9), 3295-3317.

Ericsson J., Kris J., Oviedo R. (2009). The Determinants of Credit Default Swap Premia. Journal of Financial and Quantitative Analysis, 44(1), 109-132. 
Flannery, M. J., Rangan, K. P. (2008). What Caused the Bank Capital Build-Up of the 1990s?. Review of Finance, 12(2), 391-429.

Fungacova, Z., Weill, L., Zhou, M. (2017). Bank Capital, Liquidity Creation and Deposit Insurance. Journal of Financial Services Research, 51(1), 97-123.

Galil, K., Shapir, O.M., Amiram, D., Ben-Zion, U. (2014). The Determinants of CDS Spreads. Journal of Banking \& Finance, 41, 271-282.

Gorton, G., Winton, A. (2017). Liquidity Provision, Bank Capital, and the Macroeconomy. Journal of Money, Credit and Banking, 49(1), 5-37.

Gropp, R., Heider, F. (2010). The Determinants of Bank Capital Structure. Review of Finance, 14(4), $587-622$.

Hackethal, A., Rauch, C., Steffen, S., Tyrell, M. (2010). Determinants of Bank Liquidity Creation. Available on the internet at http://ssrn.com/abstract=1343595.

Haldane, A. G., (2015). Multi-polar regulation. International Journal of Central Banking, 11(3), 385401.

Hasan I., Liuling L., Zhang G. (2015). The Determinants of Global Bank Credit-Default Swap Spreads. Journal of Financial Services Research, 50(3), 1-45.

Horvàth, R., Seidler, J., Weill, L. (2014). Bank Capital and Liquidity Creation: Granger-Causality Evidence. Journal of Financial Service Research, 45(3), 341-361.

Ippolito F., Peydrò, J.L., Polo, A., Sette, E. (2016). Double Bank Runs and Liquidity Risk Management. Journal of Financial Economics, 122(1), 135-154.

Jokipii, T., Milne, A. (2008). The Cyclical Behaviour of European Bank Capital Buffers. Journal of Banking \& Finance, 32(8), 1440-1451.

Kanagaretnam, K., Zhang, G., Zhang, S. B. (2016). CDS pricing and accounting disclosures: Evidence from U.S. bank holding corporations around the recent financial crisis. Journal of Financial Stability, 22, 33-44.

Leventis, S., Dimitropoulos, P. E., Anandarajan, A. (2011). Loan Loss Provisions, Earnings Management and Capital Management Under IFRS: The Case of EU Commercial Banks. Journal of Financial Services Research, 40(1-2), 103-122.

Merton, R. C. (1974). On the Pricing of Corporate Debt: The Risk Structure of Interest Rates. The Journal of Finance, 29(2), 449-470.

Vazquez, F., Federico, P. (2015). Bank Funding Structures and Risk: Evidence from the Global Financial Crisis. Journal of Banking \& Finance, 61, 1-14.

Volz, M., Wedow, M. (2011). Market Discipline and Too-Big-To-Fail in the CDS Market: Does Banks' Size Reduce Market Discipline?. Journal of Empirical Finance, 18(2), 195-210. 
Table 1

The banks covered in the study

\begin{tabular}{llll}
\hline Bank & Country & Bank & Country \\
\hline Erste Group Bank AG & Austria & DNB ASA & Norway \\
Raiffeisen Bank & Austria & Banco Comercial Portugues & Portugal \\
Dexia & Belgium & Banco Bilbao Vizcaya Argentaria SA & Spain \\
Danske Bank A/S & Denmark & Banco Popular & Spain \\
BNP Paribas SA & France & Banco Sabadell & Spain \\
Credit Agricole SA & France & Banco Santander SA & Spain \\
Natixis & France & Nordea Bank & Sweden \\
Societe General & France & Skandinaviska Enskilada Banken & Sweden \\
Commerzbank AG & Germany & Svenska Handelsbanken AB & Sweden \\
Deutsche Bank AG & Germany & Swedbank AB & Sweden \\
IKB Bank & Germany & Credit Suisse Group AG & Switzerland \\
Alpha Bank A.E. & Greece & UBS AG & Switzerland \\
Bank of Ireland & Ireland & Cooperatieve Centrale Raiffeisen & The Netherlands \\
Banca Popolare di Milano & Italy & ING Bank NV & The Netherlands \\
Banca Monte Paschi di Siena & Italy & Barclays Bank PLC & UK \\
Intesa Sanpaolo SPA & Italy & HSBC Bank PLC & UK \\
Mediobanca SPA & Italy & Lloyds Bank PLC & UK \\
UBI Banca & Italy & Royal Bank of Scotland PLC/The & UK \\
Unicredit SPA & Italy & Standard Chartered Bank & UK \\
\hline & & & \\
\hline & & &
\end{tabular}


Table 2

List of variables used together with their definition and summary statistics

\begin{tabular}{|c|c|c|c|c|c|}
\hline Variable & Definition & Mean & $\begin{array}{l}\text { Std. } \\
\text { Dev. }\end{array}$ & Min & Max \\
\hline Basel III leverage & $\begin{array}{l}\text { The ratio of tangible equity to total assets and off-balance } \\
\text { sheet exposures }\end{array}$ & 0.047 & 0.021 & 0.016 & 0.083 \\
\hline $\begin{array}{l}\text { Equity to Total } \\
\text { Assets }\end{array}$ & The ratio of tangible equity to total assets & 0.056 & 0.041 & 0.020 & 0.093 \\
\hline CET1 & The ratio of common equity to risk-weighted assets & 0.161 & 0.056 & 0.049 & 0.188 \\
\hline Total Capital & The ratio of Tier 1 and 2 to risk-weighted assets & 0.140 & 0.036 & 0.096 & 0.208 \\
\hline Market Capital & $\begin{array}{l}\text { The ratio of equity market value to total market value of } \\
\text { assets }\end{array}$ & 0.077 & 0.109 & 0.002 & 0.404 \\
\hline NSFR_10 & $\begin{array}{l}\text { The ratio of available stable funding to required stable fined } \\
\text { as define by the Basel III document of December } 2010\end{array}$ & 1.048 & 0.218 & 0.368 & 2.158 \\
\hline NSFR_14 & $\begin{array}{l}\text { The ratio of available stable funding to required stable fined } \\
\text { as defined by the Basel III document of December } 2014\end{array}$ & 1.072 & 0.223 & 0.381 & 2.190 \\
\hline ROE & Net income to total equity capital & 0.081 & 0.151 & -0.08 & 0.223 \\
\hline LLP/TA & The ratio of loan loss provisions to total loans & 0.236 & 0.306 & 0.001 & 0.016 \\
\hline MKT_BV & Total market value to book value & 0.883 & 0.205 & 0.546 & 1.201 \\
\hline Size & Logarithm of total assets & 5.712 & 0.563 & 4.497 & 6.564 \\
\hline GDP Growth & Percentage of GDP growth & 0.004 & 0.023 & -0.09 & 0.053 \\
\hline Interbank Spread & $\begin{array}{l}\text { Spread between the one-month interbank rate } \\
\text { and the policy rates }\end{array}$ & 0.016 & 0.0163 & -0.01 & 0.008 \\
\hline ECB Lending & ECB net lending to credit institutions & 2.649 & 0.121 & 2.206 & 2.825 \\
\hline LLR_NPL & Loan loss reserves to non-performing loans & 0.736 & 0.951 & 0.339 & 1.919 \\
\hline $\begin{array}{l}\text { Income } \\
\text { diversification }\end{array}$ & Interest income over total income & 0.530 & 3.590 & 0.227 & 0.989 \\
\hline NPL/TL & The ratio of non-performing loans to total loans & 0.059 & 0.076 & 0.004 & 0.176 \\
\hline ROA & Return on Assets & 0.005 & 0.048 & -0.008 & 0.128 \\
\hline Loans/TA & The ratio of loans to total assets & 0.530 & 0.179 & 0.195 & 0.786 \\
\hline Equity Volatility & 60 days standard deviation of bank stock returns & 40.55 & 31.25 & 15.26 & 92.77 \\
\hline Euro Stoxx & The natural logarithm of the Eurostoxx 600 index & 2.467 & 0.081 & 2.24 & 2.599 \\
\hline Term Spread & $\begin{array}{l}\text { The difference between the } 10 \text {-year government bond yield } \\
\text { for each country and the } 1 \text {-year Euribor/Libor rate }\end{array}$ & 1.629 & 2.446 & -0.64 & 6.076 \\
\hline CDS spread & The natural logarithm of CDS spread changes & 1.933 & 0.555 & 0.528 & 3.360 \\
\hline
\end{tabular}

Source: Bloomberg (2005-2015). This table reports the definitions and the descriptive statistics of all variables used in the study. 
Table 3

Bank capital and liquidity risk proxy variables

\begin{tabular}{|c|c|c|c|}
\hline Category & Proxy & Calculation & Definition \\
\hline $\begin{array}{l}\text { Risk- } \\
\text { Unweighted } \\
\text { Capital Ratio }\end{array}$ & $\begin{array}{l}\text { Basel III } \\
\text { Leverage }\end{array}$ & $\begin{array}{c}\text { Tangible Equity } \\
\text { Total Assets }+ \text { Off Balance } \\
\text { sheet Exposure }\end{array}$ & $\begin{array}{l}\text { The ratio of tangible equity } \\
\text { to total assets and off- } \\
\text { balance sheet exposures }\end{array}$ \\
\hline $\begin{array}{l}\text { Risk- } \\
\text { Unweighted } \\
\text { Capital Ratio }\end{array}$ & $\begin{array}{l}\text { Equity to } \\
\text { Total } \\
\text { Assets }\end{array}$ & $\frac{\text { Tangible Equity }}{\text { Total Assets }}$ & $\begin{array}{l}\text { The ratio of tangible equity } \\
\text { to total assets }\end{array}$ \\
\hline $\begin{array}{l}\text { Regulatory } \\
\text { Capital }\end{array}$ & CET1 & $\frac{\text { Common Equity }}{R W A}$ & $\begin{array}{l}\text { The ratio of common equity } \\
\text { to risk-weighted assets }\end{array}$ \\
\hline $\begin{array}{l}\text { Regulatory } \\
\text { Capital }\end{array}$ & $\begin{array}{l}\text { Total } \\
\text { capital }\end{array}$ & $\frac{\text { Tier } 1+\text { Tier } 2}{R W A}$ & $\begin{array}{l}\text { The ratio of Tier } 1 \text { and } 2 \text { to } \\
\text { risk-weighted assets }\end{array}$ \\
\hline Market Capital & $\begin{array}{l}\text { Market } \\
\text { Capital }\end{array}$ & $\frac{\text { Equity Market Value }}{\text { Total Market Value }}$ & $\begin{array}{l}\text { The ratio of equity market } \\
\text { value to total market value } \\
\text { of assets }\end{array}$ \\
\hline Liquidity & NSFR_10 ${ }^{\mathrm{a}}$ & $\begin{array}{c}\text { Equity }+ \text { Long Term Funding } \\
+0.95 * \text { Customer Deposits Savings } \\
+0.90 * \text { Customers } \\
\text { deposit current } \\
+0.50 * \text { Short term borrowing } \\
0.5 * \text { Securities and other short term } \\
\text { investments }+0.85 * \text { Loans }+ \\
1 * \text { Other assets } \\
+0.05 * \text { off }- \text { balance sheet items }\end{array}$ & $\begin{array}{l}\text { The ratio of available stable } \\
\text { funding to required stable } \\
\text { funding as defined by the } \\
\text { Basel III document of } \\
\text { December } 2010\end{array}$ \\
\hline Liquidity & NSFR_1 $4^{\mathrm{a}}$ & $\begin{array}{c}\text { Equity }+ \text { Long Term Funding } \\
+0.90 * \text { Customer Deposits Savings } \\
+0.80 * \text { Customer } \\
\text { deposit current } \\
+0.50 * \text { Short term borrowing } \\
0.50 * \text { Securities and other short term } \\
\text { investments }+0.85 * \text { Loans }+ \\
1 * \text { Other assets } \\
+0.05 * \text { Off }- \text { balance sheet items }\end{array}$ & $\begin{array}{l}\text { The ratio of available stable } \\
\text { funding to required stable } \\
\text { funding as defined by the } \\
\text { new Basel III document of } \\
\text { October } 2014\end{array}$ \\
\hline
\end{tabular}

This table contains the description and the calculation methodology of our target variables: capital and funding liquidity. ${ }^{a}$ Other assets are the sum of: the reserve for impaired loans, non-earning assets (total assets-total earnings assets- cash and due from banks), fixed assets, other earning assets, insurance assets, investments in property and equity investments in associates 
Table 4

The relationship between capital (Basel III regulatory framework and the equity to total assets ratios) and liquidity

\begin{tabular}{|c|c|c|c|c|}
\hline & $\begin{array}{c}\text { Basel III leverage } \\
(1 \mathrm{a})\end{array}$ & $\begin{array}{l}\text { Basel III leverage } \\
(1 \mathrm{~b})\end{array}$ & $\begin{array}{l}\text { Equity to total assets } \\
(2 \mathrm{a})\end{array}$ & $\begin{array}{l}\text { Equity to total assets } \\
(2 \mathrm{~b})\end{array}$ \\
\hline \multicolumn{5}{|l|}{ Capital equation } \\
\hline NSFR_14 & $\begin{array}{c}0.016 * * \\
(2.01)\end{array}$ & & $\begin{array}{c}0.014 * \\
(1.69)\end{array}$ & \\
\hline NSFR_10 & & $\begin{array}{c}0.016 * * \\
(1.99)\end{array}$ & & $\begin{array}{c}0.015^{*} \\
(1.71)\end{array}$ \\
\hline ROE & $\begin{array}{c}0.175^{* * *} \\
(5.10)\end{array}$ & $\begin{array}{c}0.175 * * * \\
(5.10)\end{array}$ & $\begin{array}{c}0.131 * * * \\
(7.41)\end{array}$ & $\begin{array}{c}0.131 * * * \\
(7.42)\end{array}$ \\
\hline LLP to TA & $\begin{array}{c}-0.0002 * \\
(-1.76)\end{array}$ & $\begin{array}{c}-0.0002 * \\
(-1.76)\end{array}$ & $\begin{array}{c}-0.0002 * * \\
(-2.31)\end{array}$ & $\begin{array}{c}-0.0002 * * \\
(-2.23)\end{array}$ \\
\hline MKT_BV & $\begin{array}{l}0.007 \\
(0.86)\end{array}$ & $\begin{array}{l}0.007 \\
(0.90)\end{array}$ & $\begin{array}{l}0.028 \\
(0.68)\end{array}$ & $\begin{array}{l}-0.029 \\
(-0.43)\end{array}$ \\
\hline Size & $\begin{array}{c}-0.025^{* * *} * \\
(-7.15)\end{array}$ & $\begin{array}{c}-0.025^{* * * *} \\
(-7.13)\end{array}$ & $\begin{array}{c}-0.013 * * * \\
(-12.82)\end{array}$ & $\begin{array}{c}-0.013 * * * \\
(-12.76)\end{array}$ \\
\hline GDP growth & $\begin{array}{c}0.150 * \\
(1.93)\end{array}$ & $\begin{array}{c}0.150 * \\
(1.93)\end{array}$ & $\begin{array}{l}0.043 \\
(0.85)\end{array}$ & $\begin{array}{l}0.044 \\
(087 .)\end{array}$ \\
\hline CDS spreads & $\begin{array}{l}0.082 * * * \\
(8.14)\end{array}$ & $\begin{array}{l}0.082 * * * \\
(8.14)\end{array}$ & $\begin{array}{c}0.052 * * * \\
(14.43)\end{array}$ & $\begin{array}{l}0.0563 * * \\
(14.65)\end{array}$ \\
\hline \multicolumn{5}{|l|}{ Liquidity equation } \\
\hline Capital & $\begin{array}{l}2.552^{* * * *} \\
\quad(3.50)\end{array}$ & $\begin{array}{c}2.37 * * * \\
(3.33)\end{array}$ & $\begin{array}{c}1.409 * * * \\
(3.39)\end{array}$ & $\begin{array}{l}1.384 * * * \\
(3.40)\end{array}$ \\
\hline Size & $\begin{array}{c}0.094 * * \\
(4.58)\end{array}$ & $\begin{array}{c}0.091 * * * \\
(4.57)\end{array}$ & $\begin{array}{c}0.033 * * * \\
(2.73)\end{array}$ & $\begin{array}{c}0.035 * * * \\
(2.96)\end{array}$ \\
\hline Interbank spread & $\begin{array}{c}15.977 * * * \\
(3.32)\end{array}$ & $\begin{array}{c}15.732 * * * \\
(3.32)\end{array}$ & $\begin{array}{c}13.19 * * * \\
(3.55)\end{array}$ & $\begin{array}{c}12.699 * * * \\
(3.48)\end{array}$ \\
\hline ECB lending & $\begin{array}{c}0.078 * \\
(1.59)\end{array}$ & $\begin{array}{c}0.080 * \\
(1.68)\end{array}$ & $\begin{array}{c}0.198 * * * \\
(5.01)\end{array}$ & $\begin{array}{c}0.189 * * * \\
(4.84)\end{array}$ \\
\hline GDP growth & $\begin{array}{l}-0.429 \\
(-0.84)\end{array}$ & $\begin{array}{c}-0.447 * \\
(-0.90)\end{array}$ & $\begin{array}{l}0.468 \\
(1.36)\end{array}$ & $\begin{array}{l}0.441 \\
(1.29)\end{array}$ \\
\hline CDS spreads & $\begin{array}{l}0.114 * * * \\
\quad(2.63)\end{array}$ & $\begin{array}{l}0.111 * * * \\
\quad(2.62)\end{array}$ & $\begin{array}{l}0.166^{* * * *} \\
\quad(5.10)\end{array}$ & $\begin{array}{l}0.159 * * * \\
\quad(4.96)\end{array}$ \\
\hline Hansen & 3.119 & 2.717 & 2.767 & 2.820 \\
\hline Hansen p-value & 0.210 & 0.257 & 0.250 & 0.244 \\
\hline Observations & 611 & 611 & 843 & 843 \\
\hline
\end{tabular}

This table shows the results of estimating equation system (2). The capital ratios are defined in the Basel III regulatory framework and the equity to total assets ratios. The liquidity ratios are the NSFR defined in the Basel III document of December 2010 (NSFR 2010) and the NSFR defined in the Basel III document of October 2014 (NSFR 2014). See Table 2 for the definition of the explanatory variables. Bank-level covariates enter the estimations with a one quarter lag. Endogenous variables are instrumented with their lagged values. In the Hansen test of over-identifying restrictions for the estimates the null hypothesis is that the instruments used are not correlated with residuals and so the over-identifying restrictions are valid. *, ** and *** indicate statistical significance at the $10 \%, 5 \%$ and $1 \%$ levels, respectively. Z-statistics based on robust standard errors are shown in brackets. 
Table 5

The relationship between capital (Basel II risk weighted capital ratios and the market capital ratio) and liquidity

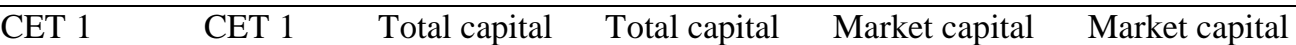

$\begin{array}{llllll}(3 a) & (3 b) & (4 a) & (4 b) & (5 a) & (5 b)\end{array}$

\section{Capital Equation}

\begin{tabular}{|c|c|c|c|c|c|c|}
\hline NSFR_14 & $\begin{array}{c}0.047 * * * \\
(3.17)\end{array}$ & & $\begin{array}{c}0.023 * * \\
(2.33)\end{array}$ & & $\begin{array}{c}-0.032 * * \\
(-2.07)\end{array}$ & \\
\hline NSFR_10 & & $\begin{array}{c}0.049 * * * \\
(3.31)\end{array}$ & & $\begin{array}{c}0.024 * * \\
(2.36)\end{array}$ & & $\begin{array}{c}-0.033 * * \\
(2.07)\end{array}$ \\
\hline ROE & $\begin{array}{c}0.03 \\
(0.25)\end{array}$ & $\begin{array}{c}0.02 \\
(0.28)\end{array}$ & $\begin{array}{c}-0.042 * * \\
(-2.44)\end{array}$ & $\begin{array}{c}-0.041 * * \\
(-2.42)\end{array}$ & $\begin{array}{c}0.406 * * * \\
(5.31)\end{array}$ & $\begin{array}{c}0.406^{* * * *} \\
(5.31)\end{array}$ \\
\hline LLP to TA & $\begin{array}{c}-0.0003 * * * \\
(-3.04)\end{array}$ & $\begin{array}{c}-0.0003 * * * \\
(-3.02)\end{array}$ & $\begin{array}{c}-0.0002 * * \\
(-2.11)\end{array}$ & $\begin{array}{c}-0.0002 * * \\
(-2.12)\end{array}$ & $\begin{array}{c}-0.0005 * * \\
(-2.25)\end{array}$ & $\begin{array}{c}-0.0005 * * \\
(-2.26)\end{array}$ \\
\hline MKT_BV & $\begin{array}{c}-0.036 * * \\
(-3.30)\end{array}$ & $\begin{array}{c}-0.037 * * \\
(3.45)\end{array}$ & $\begin{array}{l}0.006 \\
(0.73)\end{array}$ & $\begin{array}{l}0.005 \\
(0.77)\end{array}$ & $\begin{array}{c}0.037 * * \\
(2.10)\end{array}$ & $\begin{array}{c}0.037 * * \\
(2.11)\end{array}$ \\
\hline Size & $\begin{array}{c}0.023 * * * \\
(10.18)\end{array}$ & $\begin{array}{c}0.022 * * * \\
(10.11)\end{array}$ & $\begin{array}{c}0.027 * * * \\
(20.05)\end{array}$ & $\begin{array}{c}0.027 * * * \\
(20.05)\end{array}$ & $\begin{array}{c}-0.030 * * * \\
(-3.68)\end{array}$ & $\begin{array}{c}-0.305 * * * \\
(-3.67)\end{array}$ \\
\hline GDP growth & $\begin{array}{c}-0.245 * * \\
(-2.15)\end{array}$ & $\begin{array}{c}-0.245 * * * \\
(-2.63)\end{array}$ & $\begin{array}{c}-0.18 * * * \\
(-3.02)\end{array}$ & $\begin{array}{c}-0.185 * * \\
(-3.01)\end{array}$ & $\begin{array}{c}0.307^{*} \\
(1.99)\end{array}$ & $\begin{array}{c}0.305^{* * *} \\
(1.98)\end{array}$ \\
\hline CDS Spreads & $\begin{array}{c}-0.020 * * \\
(-2.42)\end{array}$ & $\begin{array}{c}-0.020 * * \\
(-2.41)\end{array}$ & $\begin{array}{c}-0.015 * * \\
(-2.83)\end{array}$ & $\begin{array}{c}-0.014 * * \\
(-2.80)\end{array}$ & $\begin{array}{c}-0.106 * * * \\
(-4.44)\end{array}$ & $\begin{array}{c}-0.106 * * * \\
(-4.43)\end{array}$ \\
\hline \multicolumn{7}{|c|}{ Liquidity equation } \\
\hline Capital & $\begin{array}{l}0.162 \\
(1.25)\end{array}$ & $\begin{array}{l}0.168 \\
(1.30)\end{array}$ & $\begin{array}{l}0.384 \\
(1.48)\end{array}$ & $\begin{array}{l}0.386 \\
(1.58)\end{array}$ & $\begin{array}{c}0.939 * \\
(1.94)\end{array}$ & $\begin{array}{c}0.921 * \\
(1.96)\end{array}$ \\
\hline Size & $\begin{array}{c}0.016^{*} \\
(1.68)\end{array}$ & $\begin{array}{c}0.018^{*} \\
(1.78)\end{array}$ & $\begin{array}{l}0.015 \\
(0.97)\end{array}$ & $\begin{array}{l}0.018 \\
(1.11)\end{array}$ & $\begin{array}{c}0.058 * * \\
(2.80)\end{array}$ & $\begin{array}{c}0.057 * * * \\
(2.85)\end{array}$ \\
\hline Interbank spread & $\begin{array}{c}18.86 * * * \\
(4.93)\end{array}$ & $\begin{array}{c}18.17 * * * \\
(4.84)\end{array}$ & $\begin{array}{c}20.48 * * * \\
(5.29)\end{array}$ & $\begin{array}{c}19.84 * * * \\
(5.23)\end{array}$ & $\begin{array}{c}15.147 * * * \\
(3.10)\end{array}$ & $\begin{array}{c}14.672 * * * \\
(3.07)\end{array}$ \\
\hline ECB lending & $\begin{array}{c}0.254 * * * \\
(5.34)\end{array}$ & $\begin{array}{c}0.246 * * * \\
(5.23)\end{array}$ & $\begin{array}{c}0.227 * * * \\
(4.94)\end{array}$ & $\begin{array}{c}0.218 * * * \\
(4.85)\end{array}$ & $\begin{array}{c}0.121^{*} \\
(1.89)\end{array}$ & $\begin{array}{c}0.119^{*} \\
(1.90)\end{array}$ \\
\hline GDP growth & $\begin{array}{l}0.341 \\
(0.90)\end{array}$ & $\begin{array}{l}0.312 \\
(0.83)\end{array}$ & $\begin{array}{l}0.262 \\
(0.70)\end{array}$ & $\begin{array}{l}0.228 \\
(0.60)\end{array}$ & $\begin{array}{l}0.740 \\
(1.26)\end{array}$ & $\begin{array}{l}0.725 \\
(1.26)\end{array}$ \\
\hline CDS spreads & $\begin{array}{c}0.171 * * * \\
(4.95)\end{array}$ & $\begin{array}{c}0.163 * * * \\
(4.81)\end{array}$ & $\begin{array}{c}0.194 * * * \\
(5.53)\end{array}$ & $\begin{array}{c}0.185^{* * * *} \\
(5.38)\end{array}$ & $\begin{array}{c}0.192 * * * \\
(4.69)\end{array}$ & $\begin{array}{c}0.186 * * * \\
(4.65)\end{array}$ \\
\hline Hansen & 1.17 & 1.09 & 1.277 & 1.190 & 0.854 & 0.696 \\
\hline Hansen p-value & 0.279 & 0.294 & 0.258 & 0.275 & 0.652 & 0.706 \\
\hline Observations & 808 & 808 & 900 & 900 & 568 & 568 \\
\hline
\end{tabular}

This table shows the results of estimating equation system (2). The capital ratios are those defined in the Basel II regulatory framework and the ratio of the market value of equity over the total market value. The liquidity ratios are the NSFR defined in the Basel III document of December 2010 (NSFR 2010) and the NSFR defined in the Basel III document of October 2014 (NSFR 2014). See Table 2 for the definition of the explanatory variables. Bank-level covariates enter the estimations with a one quarter lag. Endogenous variables are instrumented with their lagged values. In the Hansen test of overidentifying restrictions for the estimates the null hypothesis is that the instruments used are not correlated with residuals and so the over-identifying restrictions are valid. *,** and *** indicate statistical significance at the $10 \%, 5 \%$ and $1 \%$ levels, respectively. Z-statistics based on robust standard errors are shown in brackets. 
Table 6

Results of the baseline model of CDS spread changes

\begin{tabular}{|c|c|c|c|c|c|c|c|c|c|c|}
\hline & (1a) & (1b) & $(2 a)$ & (2b) & (3a) & (3b) & (4a) & (4b) & (5a) & (5b) \\
\hline \multicolumn{11}{|l|}{ Capital } \\
\hline Basel III & 0.542 & 0.531 & & & & & & & & \\
\hline leverage & $(0.47)$ & $(0.46)$ & & & & & & & & \\
\hline Equity to & & & $-0.688^{*}$ & $-0.687^{*}$ & & & & & & \\
\hline Total Assets & & & $(-1.75)$ & $(-1.74)$ & & & & & & \\
\hline \multirow[t]{2}{*}{ CET1 } & & & & & -0.125 & -0.125 & & & & \\
\hline & & & & & $(-1.01)$ & $(-1.00)$ & & & & \\
\hline Total & & & & & & & $-1.44 * * *$ & $-1.44 * *$ & & \\
\hline capital & & & & & & & $(-3.72)$ & $(-3.72)$ & & \\
\hline Market & & & & & & & & & $-0.646^{* *} *$ & $-0.645^{* *}$ \\
\hline capital & & & & & & & & & $(-2.06)$ & $(-2.06)$ \\
\hline \multicolumn{11}{|l|}{ Liquidity } \\
\hline \multirow[t]{2}{*}{ NSFR_10 } & 0.028 & & 0.054 & & 0.044 & & 0.050 & & 0.047 & \\
\hline & $(0.50)$ & & $(0.95)$ & & $(0.71)$ & & $(0.80)$ & & $(0.75)$ & \\
\hline \multirow[t]{2}{*}{ NSFR_14 } & & 0.308 & & 0.055 & & 0.046 & & 0.050 & & 0.050 \\
\hline & & $(0.55)$ & & $(0.99)$ & & $(0.74)$ & & $(0.83)$ & & $(0.79)$ \\
\hline \multicolumn{11}{|l|}{ Asset quality } \\
\hline \multirow[t]{2}{*}{$\mathrm{NPL} / \mathrm{TL}$} & $0.518 *$ & $0.519^{*}$ & $0.670^{* *}$ & $0.670 * *$ & $0.504 *$ & $0.506 *$ & 0.445 & 0.445 & 0.461 & 0.481 \\
\hline & $(1.58)$ & $(1.58)$ & $(2.30)$ & $(2.03)$ & $(1.56)$ & $(1.56)$ & (1.35) & $(1.36)$ & $(1.42)$ & $(1.43)$ \\
\hline \multicolumn{11}{|l|}{ Performance } \\
\hline \multirow[t]{2}{*}{ ROA } & $-0.282 * * *$ & $-0.282 * * *$ & $-0.267 * * *$ & $-0.267 * * *$ & $-0.374 * * *$ & $-0.374 * * *$ & $-0.295^{* * *}$ & $-0.295 * * *$ & $-0.319 * * *$ & $-0.32 * * *$ \\
\hline & $(-3.58)$ & $(-3.55)$ & $(-7.42)$ & $(-7.41)$ & $(-4.55)$ & $(-4.55)$ & $(-9.38)$ & $(-9.38)$ & $(-11.85)$ & $(-11.87)$ \\
\hline \multicolumn{11}{|c|}{ Business models } \\
\hline Income & $0.003 * * *$ & $0.003 * * *$ & $0.003 * * *$ & $0.003 * * *$ & $0.003 * * *$ & $0.003 * * *$ & $0.003 * * *$ & $0.003 * * *$ & $0.003 * * *$ & $0.003^{* * *} *$ \\
\hline Divers. & $(5.10)$ & (5.11) & $(4.70)$ & $(4.70)$ & (5.18) & (5.18) & (4.69) & $(4.70)$ & (4.77) & (4.77) \\
\hline \multirow[t]{2}{*}{ Size } & $-0.164 * * *$ & $-0.164 * * *$ & $-0.182 * * *$ & $-0.181^{* * *}$ & $-0.169 * *$ & $-0.176^{* * *}$ & $-0.154 * * *$ & $-0.154 * * *$ & $-0.178 * * *$ & $-0.18 * * *$ \\
\hline & $(-3.05)$ & $(-3.06)$ & $(-4.48)$ & $(-4.48)$ & $(-3.56)$ & $(-3.56)$ & $(-3.32)$ & $(-3.32)$ & $(-3.48)$ & $(3.48)$ \\
\hline \multicolumn{11}{|c|}{ Structural variables and market wide factors } \\
\hline Equity & $0.004 * * *$ & $0.004 * * *$ & $0.004 * * *$ & $0.004 * *$ & $0.004 * * *$ & $0.004 * * *$ & $0.004 * * *$ & $0.004 * *$ & $0.004 * * *$ & $0.004 * * *$ \\
\hline volatility & $(5.30)$ & $(5.31)$ & (4.97) & (4.97) & (5.82) & (5.83) & $(5.30)$ & $(5.31)$ & (5.02) & (5.03) \\
\hline Euro & $-1.083^{*} * *$ & $-1.083 * * *$ & $-1.10 * * *$ & $-1.10 * * *$ & $-1.02 * * *$ & $-1.02 * * *$ & $-1.05^{* * *}$ & $-1.047 * * *$ & $-0.90 * * *$ & $-0.90 * * *$ \\
\hline Stoxx & $(-4.08)$ & $(-4.08)$ & $(-4.09)$ & $(-4.09)$ & $(-3.88)$ & $(-3.88)$ & $(-3.84)$ & $(-3.85)$ & $(-3.38)$ & $(-3.38)$ \\
\hline Term & $0.033^{* * * *}$ & $0.033^{* * *} *$ & $0.033^{* * *} *$ & $0.033 * * *$ & $0.034 * * *$ & $0.034 * * *$ & $0.031 * * *$ & $0.031 * * *$ & $0.031 * * *$ & $0.031 * * *$ \\
\hline spread & $(4.88)$ & $(4.89)$ & $(4.51)$ & $(4.51)$ & (4.91) & (4.92) & (4.95) & $(4.95)$ & (4.18) & (4.18) \\
\hline \multirow[t]{2}{*}{ Constant } & $4.524 * * *$ & $4.543^{* * *}$ & $4.795^{* * *}$ & $4.791 * * * *$ & $4.462 * * *$ & $4.459 * * *$ & $4.57 * * *$ & $4.57 * * *$ & $4.274 * * *$ & 4.27 *** \\
\hline & (5.77) & $(5.77)$ & (6.13) & (6.13) & (6.01) & (6.01) & $(6.05)$ & $(6.05)$ & $(5.54)$ & $(5.54)$ \\
\hline Observations & 841 & 841 & 854 & 854 & 847 & 847 & 841 & 841 & 791 & 791 \\
\hline Time FE & $\mathrm{Y}$ & $\mathrm{Y}$ & $\mathrm{Y}$ & $\mathrm{Y}$ & $\mathrm{Y}$ & $\mathrm{Y}$ & $\mathrm{Y}$ & $\mathrm{Y}$ & $\mathrm{Y}$ & $\mathrm{Y}$ \\
\hline $\mathrm{R}^{2}$ & 0.869 & 0.87 & 0.875 & 0.875 & 0.871 & 0.871 & 0.874 & 0.874 & 0.88 & 0.88 \\
\hline $\begin{array}{l}\text { Hausman } \\
\text { (p-value) }\end{array}$ & 0.222 & 0.185 & 0.324 & 0.323 & 0.04 & 0.02 & 0.05 & 0.04 & 0.09 & 0.08 \\
\hline BP LM Test & 0.000 & 0.000 & 0.000 & 0.000 & 0.000 & 0.000 & 0.000 & 0.000 & 0.000 & 0.000 \\
\hline $\begin{array}{l}\text { Mod. Wald } \\
\text { (p-value) }\end{array}$ & 0.000 & 0.000 & 0.000 & 0.000 & 0.000 & 0.000 & 0.000 & 0.000 & 0.000 & 0.000 \\
\hline
\end{tabular}

This table shows the RE estimation results of equation (3). See Tables 2-3 for the definition of the explanatory variables. Hausman is a test to decide between fixed or random effects. The null is that the preferred model is random effects. BP LM Test is the Breusch Pagan Lagrange Multiplier test for random effects. Modified Wald is a test of homoscedasticity. $*, * *$ and $* * *$ indicate statistical significance at the $10 \%, 5 \%$ and $1 \%$ levels, respectively. Z-statistics based on robust standard errors are provided in brackets. 
Table 7

Results of the baseline model with threshold effects

\begin{tabular}{|c|c|c|c|c|c|c|c|c|c|c|}
\hline & (1a) & (1b) & (2a) & (2b) & (3a) & (3b) & (4a) & (4b) & (5a) & (5b) \\
\hline \multicolumn{11}{|l|}{ Capital } \\
\hline Basel III & 0.573 & 0.660 & & & & & & & & \\
\hline leverage & $(0.50)$ & $(0.58)$ & & & & & & & & \\
\hline Equity to & & & $-0.723 *$ & $-0.704 *$ & & & & & & \\
\hline Total Assets & & & $(-1.75)$ & $(-1.73)$ & & & & & & \\
\hline CET1 & & & & & -0.125 & -0.120 & & & & \\
\hline & & & & & $(-0.94)$ & $(-0.91)$ & & & & \\
\hline Total & & & & & & & $-1.45 * * *$ & $-1.44 * * *$ & & \\
\hline capital & & & & & & & $(3.59)$ & $(3.61)$ & & \\
\hline Market & & & & & & & & & $-0.645^{* *}$ & $-0.637 * *$ \\
\hline capital & & & & & & & & & $(-2.05)$ & $(-2.01)$ \\
\hline \multicolumn{11}{|l|}{ Liquidity } \\
\hline NSFR_10 & 0.076 & & 0.124 & & 0.033 & & 0.095 & & 0.064 & \\
\hline & $(0.91)$ & & (1.37) & & $(0.95)$ & & $(1.05)$ & & $(0.69)$ & \\
\hline NSFR_14 & & 0.111 & & $0.145^{*}$ & & $0.054^{*}$ & & $0.129 *$ & & 0.101 \\
\hline & & (1.39) & & $(1.76)$ & & $(1.63)$ & & $(1.62)$ & & (1.14) \\
\hline NSFR_10 <1 & 0.027 & & 0.028 & & $0.977 *$ & & 0.02 & & 0.008 & \\
\hline & $(0.75)$ & & $(0.74)$ & & (1.67) & & $(0.50)$ & & (0.19) & \\
\hline NSFR_14 <1 & & $0.050 *$ & & $0.047 *$ & & $0.137 * *$ & & $0.127 * *$ & & $0.032 *$ \\
\hline & & $(1.62)$ & & $(1.61)$ & & $(3.22)$ & & $(3.17)$ & & $(1.72)$ \\
\hline \multicolumn{11}{|l|}{ Asset quality } \\
\hline NPL/TL & $0.526^{*}$ & $0.521^{*}$ & $0.669 * *$ & $0.662 * *$ & $0.50^{*}$ & $0.496^{*}$ & 0.45 & 0.445 & 0.477 & 0.479 \\
\hline & $(1.54)$ & $(1.58)$ & $(1.97)$ & (1.94) & (1.54) & $(1.54)$ & (1.35) & $(1.33)$ & $(1.42)$ & $(1.41)$ \\
\hline \multicolumn{11}{|l|}{ Performance } \\
\hline Roa & $-0.27 * * *$ & $-0.27 * * *$ & $-0.26^{* *}$ & $-0.26 * * *$ & $-0.37 * * *$ & $-0.37 * * *$ & $-0.29 * * *$ & $-0.29 * * *$ & $-0.32 * * *$ & $-0.31 * * *$ \\
\hline & $(-3.59)$ & $(-3.67)$ & $(-7.11)$ & $(-7.13)$ & $(-4.40)$ & $(-4.41)$ & $(-9.97)$ & $(-10.21)$ & $(-11.87)$ & $(-11.92)$ \\
\hline \multicolumn{11}{|c|}{ Business models } \\
\hline Income & $0.003 * * *$ & $0.003 * * *$ & $0.003 * * *$ & $0.003 * * *$ & $0.003 * * *$ & $0.003 * * *$ & $0.003 * * *$ & $0.003 * * *$ & $0.003 * * *$ & $0.003 * * *$ \\
\hline Divers. & (5.15) & (5.27) & (4.65) & (4.68) & $(5.21)$ & (5.29) & $(4.61)$ & (4.66) & (4.62) & (4.60) \\
\hline Size & $-0.164 * * *$ & $-0.164 * * *$ & $-0.195 * * *$ & $-0.193 * * *$ & $-0.176^{* * *}$ & $-0.176 * * *$ & $-0.154 * * *$ & $-0.153 * * *$ & $-0.183 * * *$ & $-0.182 * * *$ \\
\hline & $(-3.02)$ & $(-2.98)$ & $(-4.45)$ & $(4.35)$ & $(-3.86)$ & $(-3.78)$ & $(-3.71)$ & $(-3.65)$ & $(-3.55)$ & $(-3.53)$ \\
\hline \multicolumn{11}{|c|}{ Structural variables and market wide factors } \\
\hline Equity & $0.004 * * *$ & $0.004 * * *$ & $0.004 * * *$ & $0.004 * *$ & $0.004 * * *$ & $0.004 * * *$ & $0.004 * * *$ & $0.004 * *$ & $0.004 * * *$ & $0.004 * * *$ \\
\hline volatility & $(5.28)$ & $(5.28)$ & $(5.04)$ & $(5.04)$ & $(5.86)$ & $(5.85)$ & $(5.26)$ & $(5.28)$ & $(5.07)$ & $(5.06)$ \\
\hline Euro & $-1.08 * * *$ & $-1.02 * * *$ & $-1.10 * * *$ & $-1.10 * * *$ & $-1.02 * * *$ & $-1.03 * * *$ & $-1.05 * * *$ & $-1.06 * * *$ & $-0.90 * * *$ & $-0.90 * * *$ \\
\hline Stoxx & $(-4.10)$ & $(-4.16)$ & $(-4.17)$ & $(-4.21)$ & $(-3.89)$ & $(-3.94)$ & $(-3.87)$ & $(-3.93)$ & $(-3.40)$ & $(-3.44)$ \\
\hline Term & $0.033 * * *$ & $0.033 * * *$ & $0.033 * * *$ & $0.033 * * *$ & $0.034 * * *$ & $0.034 * * *$ & $0.031 * * *$ & $0.031 * * *$ & $0.031 * * *$ & $0.031 * * *$ \\
\hline spread & (4.78) & (4.71) & $(4.21)$ & (4.13) & (4.66) & (4.56) & (4.50) & (4.39) & $(4.05)$ & (3.94) \\
\hline \multirow[t]{2}{*}{ Constant } & $4.478 * * *$ & $4.467 * * *$ & $4.735^{* * *}$ & $4.717 * * *$ & $4.390 * * *$ & $4.37 * * *$ & $4.54 * * *$ & $4.52 * * *$ & $4.254 * * *$ & $4.23 * * *$ \\
\hline & (5.69) & $(5.70)$ & (6.20) & $(6.22)$ & $(5.90)$ & $(5.92)$ & $(6.00)$ & (6.04) & $(5.35)$ & $(5.35)$ \\
\hline Observations & 841 & 841 & 854 & 854 & 847 & 847 & 841 & 841 & 791 & 791 \\
\hline Time FE & $\mathrm{Y}$ & $\mathrm{Y}$ & $\mathrm{Y}$ & $\mathrm{Y}$ & $\mathrm{Y}$ & $\mathrm{Y}$ & $\mathrm{Y}$ & $\mathrm{Y}$ & $\mathrm{Y}$ & $\mathrm{Y}$ \\
\hline $\mathrm{R}^{2}$ & 0.868 & 0.87 & 0.875 & 0.875 & 0.871 & 0.871 & 0.873 & 0.874 & 0.877 & 0.88 \\
\hline $\begin{array}{l}\text { Hausman } \\
\text { (p-value) }\end{array}$ & 0.203 & 0.425 & 0.40 & 0.483 & 0.08 & 0.04 & 0.03 & 0.03 & 0.08 & 0.07 \\
\hline BP LM Test & 0.000 & 0.000 & 0.000 & 0.000 & 0.000 & 0.000 & 0.000 & 0.000 & 0.000 & 0.000 \\
\hline $\begin{array}{l}\text { Mod. Wald } \\
\text { (p-value) }\end{array}$ & 0.000 & 0.000 & 0.000 & 0.000 & 0.000 & 0.000 & 0.000 & 0.000 & 0.000 & 0.000 \\
\hline
\end{tabular}

This table shows the RE estimation results of equation (3) with threshold effects. See Tables 2-3 for the definition of the explanatory variables. NSFR $10<1$ and NSFR $14<1$ are dummy variables which take value one when respectively the first and the last version of the NSFR takes a value below one. Hausman is a test to decide between fixed or random effects, the null is that the preferred model is random effects. BP LM Test is the Breusch Pagan Lagrange Multiplier test for random effects. Modified Wald is a test of homoscedasticity. $*, * *$ and $* * *$ indicate statistical significance at the $10 \%, 5 \%$ and $1 \%$ levels, respectively. Z-statistics based on robust standard errors are shown in brackets. 
Table 8

Results of the Baseline model with indirect effects of liquidity risk on CDS spread changes

\begin{tabular}{|c|c|c|c|c|c|c|c|c|c|c|}
\hline & (1a) & (1b) & (2a) & (2b) & (3a) & (3b) & (4a) & (4b) & (5a) & $(5 b)$ \\
\hline \multicolumn{11}{|l|}{ Capital } \\
\hline Basel III & 0.548 & 0.488 & & & & & & & & \\
\hline leverage & $(0.46)$ & $(0.41)$ & & & & & & & & \\
\hline Equity to & & & -0.332 & -0.424 & & & & & & \\
\hline Total Assets & & & $(-0.79)$ & $(-0.93)$ & & & & & & \\
\hline \multirow[t]{2}{*}{ CET1 } & & & & & -0.158 & -0.171 & & & & \\
\hline & & & & & $(-1.11)$ & $(-1.17)$ & & & & \\
\hline Total & & & & & & & $-1.48 * * *$ & $-1.50 * * *$ & & \\
\hline capital & & & & & & & $(-3.91)$ & $(-3.98)$ & & \\
\hline Market & & & & & & & & & $-0.687 * *$ & $-0.680^{* *}$ \\
\hline capital & & & & & & & & & $(-2.19)$ & $(-2.17)$ \\
\hline \multicolumn{11}{|l|}{ Liquidity } \\
\hline \multirow[t]{2}{*}{ NSFR_10 } & 0.028 & & -0.047 & & 0.073 & & 0.114 & & 0.061 & \\
\hline & $(0.91)$ & & $(-0.65)$ & & (1.05) & & (1.47) & & (0.99) & \\
\hline \multirow[t]{2}{*}{ NSFR_14 } & & 0.069 & & -0.019 & & 0.083 & & $0.135^{*}$ & & 0.065 \\
\hline & & (1.04) & & $(-0.30)$ & & $(1.26)$ & & $(1.84)$ & & (1.08) \\
\hline \multirow[t]{2}{*}{ Cap*NSFR_10 } & 0.011 & & $0.780 * *$ & & 0.100 & & 0.24 & & $0.135^{* *}$ & \\
\hline & $(0.20)$ & & $(2.03)$ & & $(0.74)$ & & (1.11) & & $(2.52)$ & \\
\hline \multirow[t]{2}{*}{ Cap*NSFR_14 } & & 0.633 & & $0.063^{*}$ & & 0.140 & & $0.355^{*}$ & & $0.167 * * *$ \\
\hline & & (0.94) & & (1.67) & & (0.99) & & (1.65) & & (3.13) \\
\hline \multicolumn{11}{|l|}{ Asset quality } \\
\hline \multirow[t]{2}{*}{ NPL/TL } & $0.523^{*}$ & $0.526^{*}$ & $0.823^{* * *} *$ & $0.803^{* * *}$ & $0.488^{*}$ & $0.488^{*}$ & 0.45 & 0.453 & 0.477 & 0.480 \\
\hline & $(1.56)$ & $(1.55)$ & (3.16) & (3.00) & (1.54) & $(1.54)$ & (1.34) & (1.33) & (1.43) & (1.44) \\
\hline \multicolumn{11}{|l|}{ Performance } \\
\hline \multirow[t]{2}{*}{ Roa } & $-0.27 * * *$ & $-0.28 * * *$ & $-0.27 * *$ & $-0.27 * * *$ & $-0.35 * * *$ & $-0.34 * * *$ & $-0.30 * * *$ & $-0.30 * * *$ & $-0.32 * * *$ & $-0.32 * * *$ \\
\hline & $(-3.63)$ & $(-3.54)$ & $(-7.46)$ & $(-7.27)$ & $(-4.28)$ & $(-4.32)$ & $(-9.71)$ & $(-9.90)$ & $(-11.85)$ & $(-11.96)$ \\
\hline \multicolumn{11}{|l|}{ Business models } \\
\hline Income & $0.003 * * *$ & $0.003 * * *$ & $0.003 * * *$ & $0.003 * * *$ & $0.003 * * *$ & $0.003 * * *$ & $0.003 * * *$ & $0.003^{* * *}$ & $0.003 * * *$ & $0.003 * * *$ \\
\hline Divers. & $(5.10)$ & $(5.17)$ & $(4.80)$ & $(4.73)$ & $(5.18)$ & $(5.18)$ & $(4.78)$ & (4.83) & $(4.79)$ & $(4.80)$ \\
\hline \multirow[t]{2}{*}{ Size } & $-0.16^{* * * *}$ & $-0.16^{* * *}$ & $-0.17 * * *$ & $-0.17 * * *$ & $-0.17 * * *$ & $-0.17 * * *$ & $-0.15^{* * *}$ & $-0.15^{* * *}$ & $-0.18 * * *$ & $-0.18 * * *$ \\
\hline & $(-3.00)$ & $(-3.02)$ & $(-4.07)$ & $(4.17)$ & $(-3.53)$ & $(-3.50)$ & $(-3.32)$ & $(-3.28)$ & $(-3.55)$ & $(-3.49)$ \\
\hline \multicolumn{11}{|c|}{ Structural variables and market wide factors } \\
\hline Equity & $0.004 * * *$ & $0.004 * * *$ & $0.004 * * *$ & $0.004 * *$ & $0.004 * * *$ & $0.004 * * *$ & $0.004 * * *$ & $0.004 * *$ & $0.004 * * *$ & $0.004 * * *$ \\
\hline volatility & (5.27) & $(5.30)$ & (4.98) & $(5.05)$ & (5.81) & (5.84) & $(5.25)$ & $(5.26)$ & $(5.06)$ & (5.07) \\
\hline Euro & $-1.09 * * *$ & $-1.02 * * *$ & $-1.16^{* * *}$ & $-1.13^{* * *}$ & $-1.02 * * *$ & $-1.03 * * *$ & $-1.05^{* * *}$ & $-1.06 * * *$ & $-0.90 * * *$ & $-0.90 * * *$ \\
\hline Stoxx & $(-4.09)$ & $(-4.10)$ & $(-4.56)$ & $(-4.38)$ & $(-3.90)$ & $(-3.91)$ & $(-3.87)$ & $(-3.92)$ & $(-3.37)$ & $(-3.34)$ \\
\hline Term & $0.033^{* * *} *$ & $0.033 * * *$ & $0.033^{* * *} *$ & $0.033^{* * *} *$ & $0.034 * * *$ & $0.034 * * *$ & $0.031 * * *$ & $0.031^{* * *} *$ & $0.031 * * *$ & $0.031 * * *$ \\
\hline spread & $(4.86)$ & (4.82) & (4.62) & (4.58) & (4.83) & (4.82) & $(4.74)$ & (4.69) & $(4.21)$ & $(4.19)$ \\
\hline \multirow[t]{2}{*}{ Constant } & $4.523 * * *$ & $4.488 * * *$ & $4.873 * * *$ & $4.801 * * *$ & $4.385 * * *$ & $4.37 * * *$ & $4.48 * * *$ & $4.47 * * *$ & $4.217 * * *$ & $4.18 * * *$ \\
\hline & $(5.76)$ & $(5.75)$ & (6.68) & (6.62) & $(6.00)$ & (6.01) & $(5.97)$ & $(6.00)$ & $(5.52)$ & $(5.47)$ \\
\hline Observations & 841 & 841 & 854 & 854 & 847 & 847 & 841 & 841 & 791 & 791 \\
\hline Time FE & $\mathrm{Y}$ & $\mathrm{Y}$ & $\mathrm{Y}$ & $\mathrm{Y}$ & $\mathrm{Y}$ & $\mathrm{Y}$ & Y & $\mathrm{Y}$ & $\mathrm{Y}$ & $\mathrm{Y}$ \\
\hline $\mathrm{R}^{2}$ & 0.868 & 0.868 & 0.876 & 0.876 & 0.871 & 0.871 & 0.873 & 0.874 & 0.877 & 0.88 \\
\hline $\begin{array}{l}\text { Hausman } \\
\text { (p-value) }\end{array}$ & 0.179 & 0.111 & 0.143 & 0.126 & 0.130 & 0.113 & 0.04 & 0.039 & 0.07 & 0.05 \\
\hline BP LM Test & 0.000 & 0.000 & 0.000 & 0.000 & 0.000 & 0.000 & 0.000 & 0.000 & 0.000 & 0.000 \\
\hline $\begin{array}{l}\text { Mod. Wald } \\
\text { (p-value) }\end{array}$ & 0.000 & 0.000 & 0.000 & 0.000 & 0.000 & 0.000 & 0.000 & 0.000 & 0.000 & 0.000 \\
\hline
\end{tabular}

This table shows the RE estimation results of equation (3) with capital and liquidity interactions. See Tables 2-3 for the definition of the explanatory variables. Cap*NSFR 10 and Cap*NSFR 14 are the product of the capital formulation and the dummy variables NSFR $10<1$ and NSFR $14<1$ respectively. Hausman is a test to decide between fixed or random effects, the null is that the preferred model is random effects. BP LM Test is the Breusch Pagan Lagrange Multiplier test for random effects. Modified Wald is a test of homoscedasticity. *, ** and *** indicate statistical significance at the $10 \%$, $5 \%$ and $1 \%$ levels, respectively. Z-statistics based on robust standard errors are shown in brackets. 
Table 9

Replacing LLP to TA with LLR to NPL in the capital equation

\begin{tabular}{|c|c|c|c|c|c|c|}
\hline PANEL A & $\begin{array}{c}\text { Basel III } \\
\text { Leverage } \\
\text { (1a) }\end{array}$ & $\begin{array}{c}\text { Basel III } \\
\text { Leverage } \\
\text { (1b) }\end{array}$ & $\begin{array}{l}\text { Equity to Total } \\
\text { assets } \\
\text { (2a) }\end{array}$ & $\begin{array}{l}\text { Equity to Total } \\
\text { Assets } \\
\text { (2b) }\end{array}$ & & \\
\hline \multicolumn{7}{|l|}{ Capital Equation } \\
\hline NSFR_14 & $\begin{array}{c}0.019 * * * \\
(3.11)\end{array}$ & & $\begin{array}{c}0.021 * * \\
(2.55)\end{array}$ & & & \\
\hline NSFR_10 & & $\begin{array}{c}0.019 * * * \\
(2.89)\end{array}$ & & $\begin{array}{c}0.022 * * \\
(2.60)\end{array}$ & & \\
\hline $\begin{array}{l}\text { Control } \\
\text { Variables }\end{array}$ & $\mathrm{Y}$ & $\mathrm{Y}$ & $\mathrm{Y}$ & $\mathrm{Y}$ & & \\
\hline \multicolumn{7}{|c|}{ Liquidity Equation } \\
\hline Capital & $\begin{array}{c}3.127 * * * \\
(3.39)\end{array}$ & $\begin{array}{c}2.917 * * * \\
(3.23)\end{array}$ & $\begin{array}{l}2.121 * * * \\
(4.79)\end{array}$ & $\begin{array}{c}2.076^{* *} \\
(4.84)\end{array}$ & & \\
\hline $\begin{array}{l}\text { Control } \\
\text { Variables }\end{array}$ & $\mathrm{Y}$ & $\mathrm{Y}$ & $\mathrm{Y}$ & $\mathrm{Y}$ & & \\
\hline Hansen & 0.044 & 0.043 & 0.176 & 0.214 & & \\
\hline Hansen p-value & 0.837 & 0.835 & 0.674 & 0.644 & & \\
\hline Observations & 510 & 510 & 839 & 839 & & \\
\hline PANEL B & $\begin{array}{l}\text { CET } 1 \\
\text { (3a) }\end{array}$ & $\begin{array}{l}\text { CET } 1 \\
(3 b)\end{array}$ & $\begin{array}{c}\text { Total Capital } \\
\text { (4a) }\end{array}$ & $\begin{array}{l}\text { Total Capital } \\
\text { (4b) }\end{array}$ & $\begin{array}{l}\text { Market } \\
\text { Capital } \\
(5 a)\end{array}$ & $\begin{array}{l}\text { Market } \\
\text { Capital } \\
(5 \mathrm{~b})\end{array}$ \\
\hline \multicolumn{7}{|c|}{ Capital Equation } \\
\hline NSFR_14 & $\begin{array}{c}0.065^{* * * *} \\
(4.28)\end{array}$ & & $\begin{array}{c}0.034 * * * \\
(3.03)\end{array}$ & & $\begin{array}{c}-0.090 * * * \\
(-3.18)\end{array}$ & \\
\hline NSFR_10 & & $\begin{array}{c}0.064 * * * \\
(4.23)\end{array}$ & & $\begin{array}{c}0.034 * * \\
(3.13)\end{array}$ & & $\begin{array}{c}-0.088 * * * \\
(-3.08)\end{array}$ \\
\hline $\begin{array}{l}\text { Control } \\
\text { Variables }\end{array}$ & $\mathrm{Y}$ & $\mathrm{Y}$ & $\mathrm{Y}$ & $\mathrm{Y}$ & $\mathrm{Y}$ & $\mathrm{Y}$ \\
\hline \multicolumn{7}{|c|}{ Liquidity Equation } \\
\hline Capital & $\begin{array}{l}0.333 \\
(1.57)\end{array}$ & $\begin{array}{l}0.315 \\
(1.53)\end{array}$ & $\begin{array}{c}0.831 * * * \\
(3.48)\end{array}$ & $\begin{array}{c}0.829 * * * \\
(3.54)\end{array}$ & $\begin{array}{l}0.102 * \\
(1.74)\end{array}$ & $\begin{array}{c}0.107 * \\
(1.76)\end{array}$ \\
\hline $\begin{array}{l}\text { Control } \\
\text { variables }\end{array}$ & $\mathrm{Y}$ & Y & Y & Y & Y & Y \\
\hline Hansen & 1.306 & 1.221 & 1.439 & 1.329 & 0.491 & 0.512 \\
\hline Hansen p-value & 0.253 & 0.269 & 0.230 & 0.249 & 0.483 & 0.475 \\
\hline Observations & 733 & 733 & 794 & 794 & 783 & 783 \\
\hline
\end{tabular}

This table shows the results of estimating system (2) using GMM with an alternative measure of credit risk in the capital equation. See table (2) for the definition of the explanatory variables. Bank-level covariates enter the estimations with a one quarter lag. Endogenous variables are instrumented with their lagged values. The Hansen test of over-identifying restrictions for the estimates. The null hypothesis is that the instruments used are not correlated with residuals and so the over-identifying restrictions are valid. $*, * *$ and $* * *$ indicate statistical significance at the $10 \%, 5 \%$ and $1 \%$ levels, respectively. Z-statistics based on robust standard errors are shown in brackets. 
Table 10

Replacing the NSFR with alternative liquidity proxies

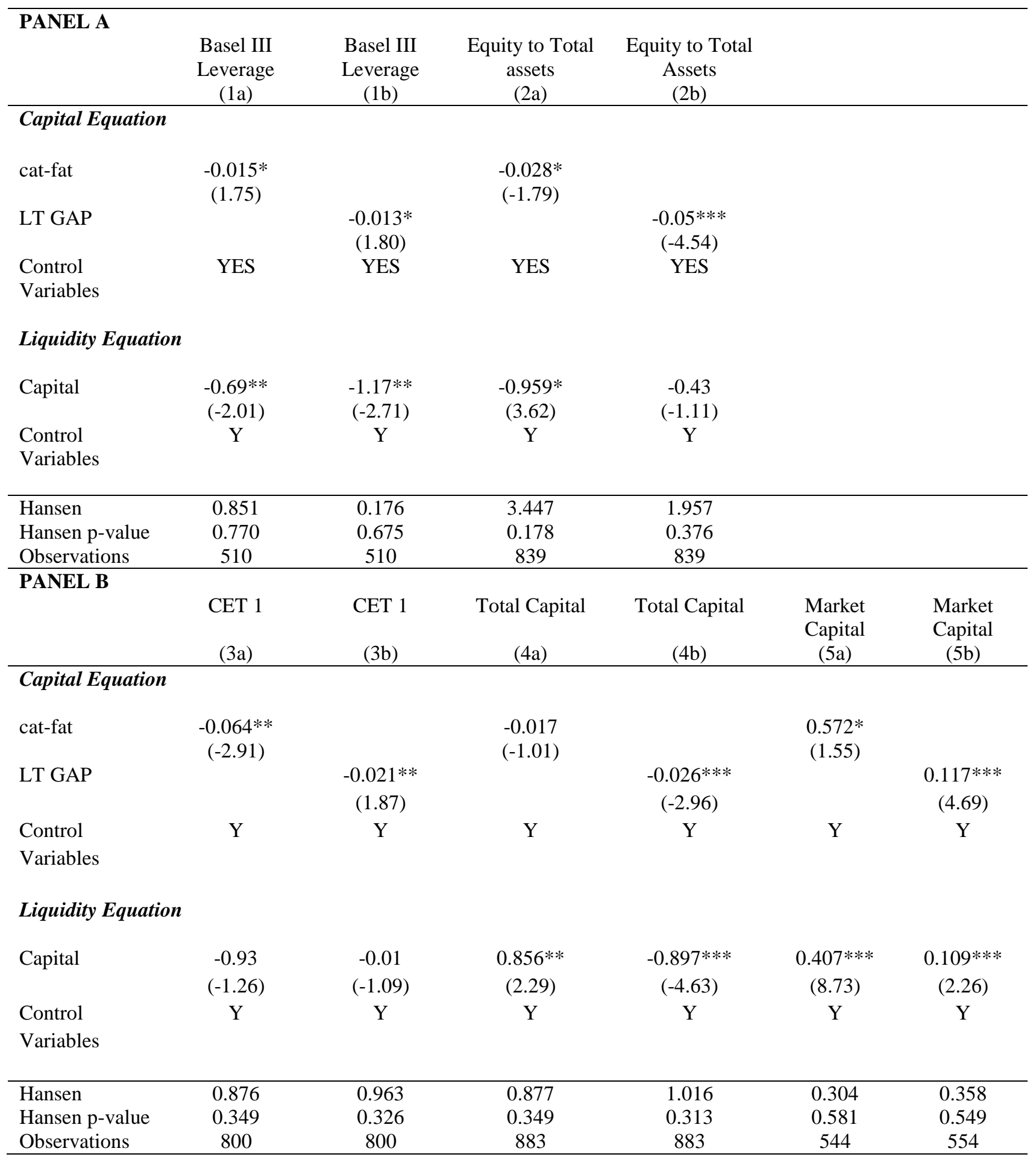

This table shows the results of estimating system (2) using GMM two alternative measures of liquidity risk in both equations. cat-fat is the "cat-fat" measure of liquidity creation defined in Berger et al. (2009). The LT GAP is the "liquidity transformation gap" (LT gap) of Deep and Schaefer (2004). The LT gap is the difference between liquid liabilities and liquid assets held by a bank divided by its total assets. See Tables 2 and 4 for the definition of the explanatory variables. Bank-level covariates enter the estimations with a one quarter lag. Endogenous variables are instrumented with their lagged values. In the Hansen test of over-identifying restrictions for the estimates the null hypothesis is that the instruments used are not correlated with residuals and so the over-identifying restrictions are valid. *, ** and *** indicate statistical significance at the $10 \%, 5 \%$ and $1 \%$ levels, respectively. Z-statistics based on robust standard errors are shown in brackets. 
Table 11

Considering income diversification in the liquidity equation

\begin{tabular}{|c|c|c|c|c|c|c|}
\hline \multicolumn{7}{|l|}{ PANEL A } \\
\hline & $\begin{array}{c}\text { Basel III } \\
\text { Leverage } \\
\text { (1a) } \\
\end{array}$ & $\begin{array}{c}\text { Basel III } \\
\text { Leverage } \\
(1 \mathrm{~b}) \\
\end{array}$ & $\begin{array}{c}\text { Equity to Total } \\
\text { assets } \\
(2 a) \\
\end{array}$ & $\begin{array}{l}\text { Equity to Total } \\
\text { Assets } \\
\text { (2b) } \\
\end{array}$ & & \\
\hline \multicolumn{7}{|l|}{ Capital Equation } \\
\hline NSFR_14 & $\begin{array}{c}0.025^{* * *} * \\
(3.29)\end{array}$ & & $\begin{array}{c}0.020 * \\
(1.84)\end{array}$ & & & \\
\hline NSFR_10 & & $\begin{array}{c}0.025 * * * \\
(3.25)\end{array}$ & & $\begin{array}{c}0.020 * \\
(2.11)\end{array}$ & & \\
\hline $\begin{array}{l}\text { Control } \\
\text { Variables }\end{array}$ & YES & YES & YES & YES & & \\
\hline \multicolumn{7}{|c|}{ Liquidity Equation } \\
\hline Capital & $\begin{array}{c}2.906^{* * * *} \\
(2.87)\end{array}$ & $\begin{array}{c}2.854 * * * \\
(2.82)\end{array}$ & $\begin{array}{c}1.798 * * \\
(4.13)\end{array}$ & $\begin{array}{c}1.776^{* * *} \\
(4.19)\end{array}$ & & \\
\hline $\begin{array}{l}\text { Control } \\
\text { Variables }\end{array}$ & $\mathrm{Y}$ & $\mathrm{Y}$ & $\mathrm{Y}$ & $\mathrm{Y}$ & & \\
\hline $\begin{array}{l}\text { Hansen } \\
\text { Hansen p-value } \\
\text { Observations }\end{array}$ & $\begin{array}{c}1.027 \\
0.311 \\
552\end{array}$ & $\begin{array}{c}1.023 \\
0.312 \\
552\end{array}$ & $\begin{array}{c}3.436 \\
0.179 \\
790\end{array}$ & $\begin{array}{c}3.436 \\
0.179 \\
790\end{array}$ & & \\
\hline PANEL B & $\begin{array}{l}\text { CET } 1 \\
(3 a) \\
\end{array}$ & $\begin{array}{l}\text { CET } 1 \\
(3 \mathrm{~b}) \\
\end{array}$ & $\begin{array}{c}\text { Total } \\
\text { Capital } \\
(4 a)\end{array}$ & $\begin{array}{c}\text { Total } \\
\text { Capital } \\
(4 \mathrm{~b})\end{array}$ & $\begin{array}{l}\text { Market } \\
\text { Capital } \\
(5 \mathrm{a})\end{array}$ & $\begin{array}{l}\text { Market } \\
\text { Capital } \\
(5 \mathrm{~b}) \\
\end{array}$ \\
\hline \multicolumn{7}{|l|}{ Capital Equation } \\
\hline NSFR_14 & $\begin{array}{c}0.052 * * * \\
(3.339)\end{array}$ & & $\begin{array}{c}0.022 * * \\
(2.15)\end{array}$ & & $\begin{array}{c}-0.026 * \\
(-1.71)\end{array}$ & \\
\hline NSFR_10 & & $\begin{array}{c}0.056^{* * *} * \\
(3.54)\end{array}$ & & $\begin{array}{c}0.023 * * \\
(2.19)\end{array}$ & & $\begin{array}{c}-0.027 * \\
(-1.73)\end{array}$ \\
\hline $\begin{array}{l}\text { Control } \\
\text { Variables }\end{array}$ & $\mathrm{Y}$ & $\mathrm{Y}$ & $\mathrm{Y}$ & $\mathrm{Y}$ & $\mathrm{Y}$ & $\mathrm{Y}$ \\
\hline \multicolumn{7}{|c|}{ Liquidity Equation } \\
\hline Capital & $\begin{array}{l}0.136 \\
(1.07)\end{array}$ & $\begin{array}{l}0.144 \\
(1.12)\end{array}$ & $\begin{array}{l}0.309 \\
(1.27)\end{array}$ & $\begin{array}{l}0.317 \\
(1.33)\end{array}$ & $\begin{array}{c}1.549 * * * \\
(2.75)\end{array}$ & $\begin{array}{c}1.544 * * * \\
(2.83)\end{array}$ \\
\hline $\begin{array}{l}\text { Control } \\
\text { Variables }\end{array}$ & $\mathrm{Y}$ & $\mathrm{Y}$ & $\mathrm{Y}$ & $\mathrm{Y}$ & $\mathrm{Y}$ & $\mathrm{Y}$ \\
\hline Hansen & 1.171 & 1.101 & 1.268 & 1.184 & 1.364 & 1.184 \\
\hline Hansen p-value & 0.279 & 0.294 & 0.260 & 0.276 & 0.505 & 0.553 \\
\hline Observations & 760 & 760 & 848 & 848 & 509 & 509 \\
\hline
\end{tabular}

This table shows the results of estimating system (2) using GMM and considering income diversification in the liquidity equation. Income diversification is the ratio of interest income over total income. See Tables 2 and 4 for the definition of the explanatory variables. Bank-level covariates enter the estimations with a one quarter lag. Endogenous variables are instrumented with their lagged values. In the Hansen test of over-identifying restrictions for the estimates the null hypothesis is that the instruments used are not correlated with residuals and so the over-identifying restrictions are valid. $*$, ** and $* * *$ indicate statistical significance at the $10 \%, 5 \%$ and $1 \%$ levels, respectively. Z-statistics based on robust standard errors are shown in brackets. 
Table 12

Liquidity risk management during the crisis

\begin{tabular}{|c|c|c|}
\hline & NSFR_10 & NSFR_14 \\
\hline NPL/TL $t-1$ & $\begin{array}{c}-0.431 * * \\
(-2.63)\end{array}$ & $\begin{array}{c}-0.443 * * \\
(-2.67)\end{array}$ \\
\hline$\Delta$ Loans & $\begin{array}{c}0.194 * * \\
(2.70)\end{array}$ & $\begin{array}{c}0.195^{* *} \\
(2.66)\end{array}$ \\
\hline$\Delta$ Loans $*$ Interbank spread & $\begin{array}{c}32.078^{*} \\
(1.76)\end{array}$ & $\begin{array}{c}32.317 * * \\
(1.76)\end{array}$ \\
\hline Deposit/Total Funding $\mathrm{t}_{\mathrm{t}-1}$ & $\begin{array}{l}0.149 \\
(1.05)\end{array}$ & $\begin{array}{l}0.190 \\
(1.32)\end{array}$ \\
\hline Deposit/Total Funding $\mathrm{t}_{\mathrm{t}-1} *$ Interbank spread & $\begin{array}{l}17.834 \\
(1.66)\end{array}$ & $\begin{array}{l}18.550 \\
(1.69)\end{array}$ \\
\hline Basel III leverage $_{t-1}$ & $\begin{array}{l}0.593 \\
(0.45)\end{array}$ & $\begin{array}{l}0.575 \\
(0.72)\end{array}$ \\
\hline Basel III leverage $t_{t-1} *$ Interbank spread & $\begin{array}{c}-27.548 * * \\
(-2.57)\end{array}$ & $\begin{array}{c}-27.832 * * \\
(-2.57)\end{array}$ \\
\hline Size $_{t-1}$ & $\begin{array}{l}-0.033 \\
(-0.26)\end{array}$ & $\begin{array}{l}-0.032 \\
(-0.26)\end{array}$ \\
\hline Size $^{*}$ Interbank spread ${ }_{\mathrm{t}-1}$ & $\begin{array}{c}-5.757 * * \\
(-2.21)\end{array}$ & $\begin{array}{c}-5.751 * * \\
(-2.19)\end{array}$ \\
\hline Observations & 954 & 954 \\
\hline Quarterly Dummies & Y & Y \\
\hline Bank fixed effects & Y & Y \\
\hline $\mathrm{R}^{2}$ adjusted & 0.173 & 0.183 \\
\hline
\end{tabular}

This table test the liquidity management assumptions during the crisis. The dependent variables are NSFR 2010 and NSFR 2014, respectively. NPL/TL $\mathrm{t}_{-1}$ is the ratio of non-performing loans over total loans of the previous quarter. We use this variable to examine the connections between funding liquidity risk and credit risk of the loan portfolio. We include the variation of loans over total loans, the ratio of deposits over total funding, the Basel III leverage ratio and the logarithm of total assets (size). All the mentioned variables are interacted with the interbank spread as defined in table (2) to take in consideration the effect of the crisis. We control for bank fixed effects and time fixed effects using quarterly dummies. *, $* *$ and $* * *$ indicate statistical significance at the $10 \%, 5 \%$ and $1 \%$ levels, respectively. Z-statistics based on robust standard errors are shown in brackets. 
Table 13

IV-RE Baseline model

\begin{tabular}{|c|c|c|c|c|c|c|c|c|c|c|}
\hline & (1a) & (1b) & (2a) & (2b) & (3a) & (3b) & (4a) & (4b) & (5a) & (5b) \\
\hline \multicolumn{11}{|l|}{ Capital } \\
\hline Basel III & 0.684 & 0.690 & & & & & & & & \\
\hline leverage & $(0.50)$ & $(0.50)$ & & & & & & & & \\
\hline Equity to & & & -0.549 & -0.560 & & & & & & \\
\hline Total Assets & & & $(-0.36)$ & $(-0.37)$ & & & & & & \\
\hline CET1 & & & & & $-1.358 * *$ & $-1.364 * *$ & & & & \\
\hline & & & & & $(-2.05)$ & $(-2.07)$ & & & & \\
\hline Total & & & & & & & $-1.482 * * *$ & $-1.489 * * *$ & & \\
\hline capital & & & & & & & $(-3.01)$ & $(-3.03)$ & & \\
\hline Market & & & & & & & & & $-0.653 * *$ & $-0.654 * *$ \\
\hline capital & & & & & & & & & $(-2.13)$ & $(-2.14)$ \\
\hline \multicolumn{11}{|l|}{ Liquidity } \\
\hline \multirow[t]{2}{*}{ NSFR_10 } & -0.129 & & -0.104 & & -0.108 & & -0.106 & & -0.155 & \\
\hline & $(-1.23)$ & & $(-1.05)$ & & $(-0.87)$ & & $(-1.11)$ & & $(-1.12)$ & \\
\hline \multirow[t]{2}{*}{ NSFR_14 } & & -0.127 & & -0.096 & & -0.103 & & -0.102 & & -0.146 \\
\hline & & $(-1.23)$ & & $(-0.99)$ & & $(-0.85)$ & & $(-1.09)$ & & $(-1.09)$ \\
\hline \multicolumn{11}{|l|}{ Asset quality } \\
\hline NPL/TL & $\begin{array}{c}1.08 * * * \\
(4.76)\end{array}$ & $\begin{array}{c}1.08 * * * \\
(4.75)\end{array}$ & $\begin{array}{c}1.10 * * * \\
(4.75)\end{array}$ & $\begin{array}{c}1.10 * * * \\
(4.75)\end{array}$ & $\begin{array}{c}1.02 * * * \\
(4.10)\end{array}$ & $\begin{array}{c}1.024 * * * \\
(4.18)\end{array}$ & $\begin{array}{l}1.0 * * * \\
(4.01)\end{array}$ & $\begin{array}{c}1.01 * * * \\
(4.00)\end{array}$ & $\begin{array}{c}0.978 * * * \\
(3.84)\end{array}$ & $\begin{array}{c}0.978 * * * \\
(3.83)\end{array}$ \\
\hline \multicolumn{11}{|l|}{ Performance } \\
\hline \multirow[t]{2}{*}{ ROA } & 0.894 & 0.889 & 1.079 & 1.789 & 1.34 & 1.33 & 1.42 & 1.41 & $-2.34 * *$ & $-2.33 * *$ \\
\hline & $(0.58)$ & $(0.57)$ & (1.09) & (1.09) & $(1.32)$ & (1.30) & (1.17) & (1.16) & $(-2.44)$ & $(-2.41)$ \\
\hline \multicolumn{11}{|c|}{ Business models } \\
\hline Income & $0.003 * * *$ & $0.003 * * *$ & $0.003 * * *$ & $0.003 * * *$ & $0.003 * * *$ & $0.003 * * *$ & $0.003 * * *$ & $0.003 * * *$ & $0.003 * * *$ & $0.003 * * *$ \\
\hline Divers. & $(5.25)$ & $(5.25)$ & $(4.82)$ & $(4.83)$ & $(4.76)$ & (4.77) & $(4.91)$ & $(4.91)$ & $(4.97)$ & $(4.97)$ \\
\hline Size & $-0.158 * * *$ & $-0.158 * * *$ & $-0.17 * * *$ & $-0.17 * * *$ & $-0.121 * *$ & $-0.121 * *$ & $-0.139 * * *$ & $-0.139 * * *$ & $-0.161 * * *$ & $-0.161 * * *$ \\
\hline & $(-2.77)$ & $(-2.77)$ & $(-2.99)$ & $(-2.99)$ & $(-1.99)$ & $(-1.99)$ & $(-3.15)$ & $(-3.15)$ & $(-2.91)$ & $(-2.91)$ \\
\hline \multicolumn{11}{|c|}{ Structural variables and market wide factors } \\
\hline $\begin{array}{l}\text { Equity } \\
\text { volatility }\end{array}$ & $\begin{array}{c}0.003 * * * \\
(4.49)\end{array}$ & $\begin{array}{c}0.003 * * * \\
(4.48)\end{array}$ & $\begin{array}{c}0.003 * * * \\
(4.70)\end{array}$ & $\begin{array}{c}0.003 * * * \\
(4.71)\end{array}$ & $\begin{array}{c}0.003 * * * \\
(4.76)\end{array}$ & $\begin{array}{c}0.003 * * * \\
(4.43)\end{array}$ & $\begin{array}{c}0.003 * * * \\
(4.26)\end{array}$ & $\begin{array}{c}0.003 * * * \\
(4.26)\end{array}$ & $\begin{array}{c}0.003 * * * \\
(4.33)\end{array}$ & $\begin{array}{c}0.003 * * * \\
(4.33)\end{array}$ \\
\hline Euro & $-1.320 * * *$ & $-1.321 * * *$ & $-1.313^{* * *}$ & $-1.313 * * *$ & $-1.34 * * *$ & $-1.343 * * *$ & $-1.304 * * *$ & $-1.304 * * *$ & $-1.134 * * *$ & $-1.134 * * *$ \\
\hline Stoxx & $(-5.25)$ & $(-5.25)$ & $(-5.33)$ & $(-5.33)$ & $(-5.00)$ & $(-5.00)$ & $(-4.88)$ & $(-4.88)$ & $(-4.45)$ & $(-4.45)$ \\
\hline Term & $0.033 * * *$ & $0.033 * * *$ & $0.033 * * *$ & $0.033 * * *$ & $0.033 * * *$ & $0.034 * * *$ & $0.032 * * *$ & $0.032 * * *$ & $0.034 * * *$ & $0.034 * * *$ \\
\hline spread & (5.81) & $(5.81)$ & $(5.38)$ & $(5.39)$ & (5.38) & $(5.38)$ & $(6.24)$ & $(6.25)$ & (5.21) & $(5.22)$ \\
\hline \multirow[t]{2}{*}{ Constant } & $5.288 * * *$ & $5.29 * * *$ & $5.32 * * *$ & $5.32 * * *$ & $5.219 * * *$ & $5.219 * * *$ & $5.312 * * *$ & $5.313 * * *$ & $4.926 * * *$ & $4.92 * * *$ \\
\hline & (6.95) & (6.94) & $(7.35)$ & $(7.35)$ & $(6.46)$ & $(6.47)$ & $(7.16)$ & (7.16) & $(6.74)$ & $(6.73)$ \\
\hline Observations & 841 & 841 & 854 & 854 & 847 & 847 & 841 & 841 & 791 & 791 \\
\hline Time FE & $\mathrm{Y}$ & $\mathrm{Y}$ & $\mathrm{Y}$ & $\mathrm{Y}$ & $\mathrm{Y}$ & $\mathrm{Y}$ & $\mathrm{Y}$ & $\mathrm{Y}$ & $\mathrm{Y}$ & $\mathrm{Y}$ \\
\hline $\mathrm{R}^{2}$ & 0.867 & 0.87 & 0.868 & 0.868 & 0.864 & 0.864 & 0.874 & 0.876 & 0.871 & 0.871 \\
\hline
\end{tabular}

This table shows the estimations IV-RE of equation (3). See Tables 2-3 for the definition of the explanatory variables. $z$ statistics based on robust standard errors are provided in brackets. *, ** and *** indicate statistical significance at the $10 \%$, $5 \%$ and $1 \%$ levels, respectively. Z-statistics based on robust standard errors are shown in brackets. 
Table 14

IV-RE Model with threshold effects

\begin{tabular}{|c|c|c|c|c|c|c|c|c|c|c|}
\hline & (1a) & (1b) & $(2 a)$ & (2b) & (3a) & (3b) & (4a) & (4b) & (5a) & $(5 b)$ \\
\hline \multicolumn{11}{|l|}{ Capital } \\
\hline Basel III & 0.460 & 0.553 & & & & & & & & \\
\hline leverage & $(0.29)$ & $(0.35)$ & & & & & & & & \\
\hline Equity to & & & 0.163 & 0.29 & & & & & & \\
\hline Total Assets & & & $(0.10)$ & $(0.19)$ & & & & & & \\
\hline \multirow[t]{2}{*}{ CET1 } & & & & & -0.728 & -0.724 & & & & \\
\hline & & & & & $(-1.21)$ & $(-1.22)$ & & & & \\
\hline Total & & & & & & & $-1.30 * * *$ & $-1.28 * * *$ & & \\
\hline capital & & & & & & & $(-2.57)$ & $(-2.63)$ & & \\
\hline Market & & & & & & & & & $-0.495 * * *$ & $-0.487 * * *$ \\
\hline capital & & & & & & & & & $(-2.75)$ & $(-2.58)$ \\
\hline \multicolumn{11}{|l|}{ Liquidity } \\
\hline NSFR_10 & 0.057 & & 0.049 & & 0.051 & & 0.02 & & 0.047 & \\
\hline$<1$ & $(1.23)$ & & $(1.15)$ & & $(1.12)$ & & $(0.61)$ & & $(0.88)$ & \\
\hline NSFR_14 & & $0.787 * *$ & & $0.069 *$ & & $0.072 *$ & & $0.056^{*}$ & & $0.054 *$ \\
\hline$<1$ & & (1.96) & & $(1.72)$ & & $(1.70)$ & & (1.67) & & $(1.78)$ \\
\hline \multicolumn{11}{|l|}{ Asset quality } \\
\hline NPL/TL & $\begin{array}{c}1.05 * * * \\
(4.00)\end{array}$ & $\begin{array}{c}1.03 * * * \\
(3.97)\end{array}$ & $\begin{array}{c}1.07 * * * \\
(3.99)\end{array}$ & $\begin{array}{c}1.07 * * * \\
(3.97)\end{array}$ & $\begin{array}{c}0.975^{* * *} \\
(3.32)\end{array}$ & $\begin{array}{c}0.976^{* * * *} \\
(3.35)\end{array}$ & $\begin{array}{c}0.913 \text { *** } \\
(3.13)\end{array}$ & $\begin{array}{c}0.916^{* * * *} \\
(3.18)\end{array}$ & $\begin{array}{c}1.014 * * * \\
(3.37)\end{array}$ & $\begin{array}{c}1.01 * * * \\
(3.36)\end{array}$ \\
\hline \multicolumn{11}{|l|}{ Performance } \\
\hline \multirow[t]{2}{*}{ Roa } & 0.280 & 0.379 & 0.440 & 0.49 & 0.04 & 0.064 & 0.788 & 0.956 & 1.07 & 1.04 \\
\hline & $(0.30)$ & $(0.41)$ & $(0.46)$ & $(0.53)$ & $(0.40)$ & $(0.60)$ & $(0.71)$ & $(0.88)$ & $(1.15)$ & (1.13) \\
\hline \multicolumn{11}{|c|}{ Business models } \\
\hline Income & $0.003 * * *$ & $0.003^{* * *}$ & $0.003^{* * *}$ & $0.003 * * *$ & $0.003^{* * *}$ & $0.003^{* * *}$ & $0.003^{* * *}$ & $0.003 * * *$ & $0.003 * * *$ & $0.003 * * *$ \\
\hline Divers. & $(5.73)$ & $(6.03)$ & $(5.06)$ & $(5.26)$ & $(4.61)$ & (4.74) & $(4.73)$ & $(4.84)$ & $(4.92)$ & $(4.75)$ \\
\hline Size & $-0.215^{* * *}$ & $-0.213^{* * *}$ & $-0.217 * * *$ & $-0.213^{* * *}$ & $-0.199 * * *$ & $-0.197 * * *$ & $-0.197 * * *$ & $-0.195 * * *$ & $-0.229 * * *$ & $-0.229 * * *$ \\
\hline & $(-4.04)$ & $(-4.04)$ & $(-4.14)$ & $(-4.03)$ & $(-4.10)$ & $(-4.12)$ & $(-4.64)$ & $(-4.71)$ & $(-4.33)$ & $(-4.27)$ \\
\hline \multicolumn{11}{|c|}{ Structural variables and market wide factors } \\
\hline $\begin{array}{l}\text { Equity } \\
\text { volatility }\end{array}$ & $\begin{array}{c}0.003 * * * \\
(3.23)\end{array}$ & $\begin{array}{c}0.003 * * * \\
(3.23)\end{array}$ & $\begin{array}{c}0.003^{* * *} \\
(3.25)\end{array}$ & $\begin{array}{c}0.003^{* *} * \\
(3.26)\end{array}$ & $\begin{array}{c}0.003 * * * \\
(3.56)\end{array}$ & $\begin{array}{c}0.003^{* * *} \\
(3.54)\end{array}$ & $\begin{array}{c}0.003 * * * \\
(3.42)\end{array}$ & $\begin{array}{c}0.003^{* *} \\
(3.37)\end{array}$ & $\begin{array}{c}0.003 * * * \\
(3.23)\end{array}$ & $\begin{array}{c}0.003 * * * \\
(3.30)\end{array}$ \\
\hline Euro & $-1.441 * * *$ & $-1.441 * * *$ & $-1.45 * * *$ & $-1.46^{* * *}$ & $-1.414 * * *$ & $-1.427 * * *$ & $-1.410 * * *$ & $-1.43^{* * *} *$ & $-1.298 * * *$ & $-1.29 * * *$ \\
\hline Stoxx & $(-4.39)$ & $(-4.39)$ & $(-4.48)$ & $(-4.49)$ & $(-4.30)$ & $(-4.31)$ & $(-4.37)$ & $(-4.39)$ & $(-3.96)$ & $(-3.97)$ \\
\hline Term & $0.034 * * *$ & $0.034^{* * *} *$ & $0.033^{* * *}$ & $0.033 * * *$ & $0.034 * * *$ & $0.034 * * *$ & $0.033^{* * *} *$ & $0.033 * * *$ & $0.034 * * *$ & $0.034 * * *$ \\
\hline spread & (4.97) & (4.95) & $(4.80)$ & $(4.72)$ & $(5.36)$ & $(5.23)$ & (5.89) & $(5.72)$ & (4.53) & $(4.50)$ \\
\hline Constant & $5.863 * * *$ & $5.864 * * *$ & $5.932 * * *$ & $5.924 * * *$ & $5.778 * * *$ & $5.789 * * *$ & $5.878 * * *$ & $5.89 * * *$ & $5.690 * * *$ & $5.68 * * *$ \\
\hline & $(6.40)$ & (6.36) & (6.54) & (6.48) & (6.55) & (6.51) & (7.04) & $(7.01)$ & (6.32) & $(6.30)$ \\
\hline Observations & 841 & 841 & 854 & 854 & 847 & 847 & 841 & 841 & 791 & 791 \\
\hline Time FE & $\mathrm{Y}$ & $\mathrm{Y}$ & $\mathrm{Y}$ & $\mathrm{Y}$ & $\mathrm{Y}$ & $\mathrm{Y}$ & $\mathrm{Y}$ & $\mathrm{Y}$ & $\mathrm{Y}$ & $\mathrm{Y}$ \\
\hline $\mathrm{R}^{2}$ & 0.869 & 0.87 & 0.867 & 0.867 & 0.867 & 0.871 & 0.875 & 0.876 & 0.88 & 0.88 \\
\hline
\end{tabular}

This table shows the estimations of IV-RE of equation (3) with threshold effects. See Tables 2-3 for the definition of the explanatory variables. *,** and *** indicate statistical significance at the $10 \%, 5 \%$ and $1 \%$ levels, respectively. Z-statistics based on robust standard errors are shown in brackets. 
Table 15

RE model with AR(1) disturbance

\begin{tabular}{|c|c|c|c|c|c|c|c|c|c|c|}
\hline & (1a) & (1b) & $(2 a)$ & (2b) & (3a) & (3b) & (4a) & (4b) & $(5 a)$ & (5b) \\
\hline \multicolumn{11}{|l|}{ Capital } \\
\hline Basel III & 0.647 & 0.681 & & & & & & & & \\
\hline leverage & $(0.12)$ & $(0.12)$ & & & & & & & & \\
\hline Equity to & & & $-0.788 * * *$ & $-0.786^{* * *}$ & & & & & & \\
\hline Total Assets & & & $(-2.75)$ & $(-2.75)$ & & & & & & \\
\hline CET1 & & & & & $\begin{array}{l}-0.138 \\
(-1.44)\end{array}$ & $\begin{array}{l}-0.138 \\
(-1.43)\end{array}$ & & & & \\
\hline $\begin{array}{l}\text { Total } \\
\text { capital }\end{array}$ & & & & & & & $\begin{array}{c}-1.44 * * * \\
(-4.94)\end{array}$ & $\begin{array}{c}-1.44 * * \\
(-4.93)\end{array}$ & & \\
\hline $\begin{array}{l}\text { Market } \\
\text { capital }\end{array}$ & & & & & & & & & $\begin{array}{c}-0.633 * * * \\
(-5.04)\end{array}$ & $\begin{array}{c}-0.63 * * * \\
(-5.04)\end{array}$ \\
\hline \multicolumn{11}{|l|}{ Liquidity } \\
\hline NSFR_10 & $\begin{array}{l}0.050 \\
(1.02)\end{array}$ & & $\begin{array}{l}0.060 \\
(1.30)\end{array}$ & & $\begin{array}{l}0.052 \\
(1.07)\end{array}$ & & $\begin{array}{l}0.058 \\
(1.20)\end{array}$ & & $\begin{array}{l}0.042 \\
(0.90)\end{array}$ & \\
\hline NSFR_14 & & $\begin{array}{l}0.051 \\
(1.05)\end{array}$ & & $\begin{array}{l}0.059 \\
(1.31)\end{array}$ & & $\begin{array}{l}0.051 \\
(1.09)\end{array}$ & & $\begin{array}{l}0.057 \\
(1.21)\end{array}$ & & $\begin{array}{l}0.043 \\
(0.93)\end{array}$ \\
\hline \multicolumn{11}{|l|}{ Asset quality } \\
\hline NPL/TL & $\begin{array}{c}0.431 * * * \\
(3.63)\end{array}$ & $\begin{array}{c}0.431 * * * \\
(3.64)\end{array}$ & $\begin{array}{c}0.615^{* * *} * \\
(4.59)\end{array}$ & $\begin{array}{c}0.615^{* * * *} \\
(4.59)\end{array}$ & $\begin{array}{c}0.428 * * * \\
(3.69)\end{array}$ & $\begin{array}{c}0.429 * * * \\
(3.70)\end{array}$ & $\begin{array}{c}0.394 * * * \\
(3.32)\end{array}$ & $\begin{array}{c}0.394 * * * \\
(3.32)\end{array}$ & $\begin{array}{c}0.324 * * * \\
(2.83)\end{array}$ & $\begin{array}{c}0.326 * * * \\
(2.84)\end{array}$ \\
\hline \multicolumn{11}{|l|}{ Performance } \\
\hline ROA & $\begin{array}{c}-0.254^{*} \\
(-1.76)\end{array}$ & $\begin{array}{c}-0.254 * * * \\
(-1.76)\end{array}$ & $\begin{array}{c}-0.232 * * * \\
(-2.20)\end{array}$ & $\begin{array}{c}-0.233 * * * \\
(-2.20)\end{array}$ & $\begin{array}{c}-0.358 * * * \\
(-3.29)\end{array}$ & $\begin{array}{c}-0.358 * * * \\
(-3.29)\end{array}$ & $\begin{array}{c}-0.269 * * * \\
(-2.56)\end{array}$ & $\begin{array}{c}-0.269 * * * \\
(-2.56)\end{array}$ & $\begin{array}{c}-0.303 * * * \\
(-2.93)\end{array}$ & $\begin{array}{c}-0.30 * * * \\
(-2.93)\end{array}$ \\
\hline \multicolumn{11}{|c|}{ Business models } \\
\hline $\begin{array}{l}\text { Income } \\
\text { Divers. }\end{array}$ & $\begin{array}{c}0.003^{* * *} * \\
(3.17)\end{array}$ & $\begin{array}{c}0.003^{* * * *} \\
(3.17)\end{array}$ & $\begin{array}{c}0.003^{* * *} * \\
(3.20)\end{array}$ & $\begin{array}{c}0.003 * * * \\
(3.20)\end{array}$ & $\begin{array}{c}0.003^{* * *} * \\
(3.15)\end{array}$ & $\begin{array}{c}0.003^{* * * *} \\
(3.15)\end{array}$ & $\begin{array}{c}0.003 * * * \\
(2.97)\end{array}$ & $\begin{array}{c}0.003 * * * \\
(2.97)\end{array}$ & $\begin{array}{c}0.003^{* * *} * \\
(3.06)\end{array}$ & $\begin{array}{c}0.003 * * * \\
(3.06)\end{array}$ \\
\hline Size & $\begin{array}{c}-0.183 * * * \\
(-6.29)\end{array}$ & $\begin{array}{c}-0.183 * * * \\
(-6.29)\end{array}$ & $\begin{array}{c}-0.191 * * * \\
(-7.59)\end{array}$ & $\begin{array}{c}-0.190 * * * \\
(-7.58)\end{array}$ & $\begin{array}{c}-0.179 * * \\
(-6.70)\end{array}$ & $\begin{array}{c}-0.179 * * * \\
(-6.69)\end{array}$ & $\begin{array}{c}-0.151 * * * \\
(-5.46)\end{array}$ & $\begin{array}{c}-0.154 * * * \\
(-5.46)\end{array}$ & $\begin{array}{c}-0.197 * * * \\
(-7.35)\end{array}$ & $\begin{array}{c}-0.19 * * * \\
(-7.34)\end{array}$ \\
\hline \multicolumn{11}{|c|}{ Structural variables and market wide factors } \\
\hline $\begin{array}{l}\text { Equity } \\
\text { volatility }\end{array}$ & $\begin{array}{c}0.003^{* * *} * \\
(8.60)\end{array}$ & $\begin{array}{c}0.003^{* * * *} \\
(8.61)\end{array}$ & $\begin{array}{c}0.003^{* * * *} \\
(8.33)\end{array}$ & $\begin{array}{c}0.003 * * \\
(8.34)\end{array}$ & $\begin{array}{c}0.003^{* * *} * \\
(8.78)\end{array}$ & $\begin{array}{c}0.003 * * * \\
(8.78)\end{array}$ & $\begin{array}{c}0.003 * * * \\
(8.59)\end{array}$ & $\begin{array}{c}0.003 * * \\
(8.59)\end{array}$ & $\begin{array}{c}0.004^{* * * *} \\
(8.19)\end{array}$ & $\begin{array}{c}0.003 * * * \\
(8.20)\end{array}$ \\
\hline Euro & $-1.353 * * *$ & $-1.352 * * *$ & $-1.342 * * *$ & $-1.34 * * *$ & $-1.27 * * *$ & $-1.27 * * *$ & $-1.29 * * *$ & $-1.295 * * *$ & $-1.16 * * *$ & -1.16 *** \\
\hline Stoxx & $(-7.43)$ & $(-7.42)$ & $(-7.43)$ & $(-7.43)$ & $(-6.95)$ & $(-6.94)$ & $(-7.21)$ & $(-7.20)$ & $(-6.23)$ & $(-6.23)$ \\
\hline $\begin{array}{l}\text { Term } \\
\text { spread }\end{array}$ & $\begin{array}{c}0.032 * * * \\
(8.63)\end{array}$ & $\begin{array}{c}0.033^{* * * *} \\
(8.63)\end{array}$ & $\begin{array}{c}0.032 * * * \\
(8.71)\end{array}$ & $\begin{array}{c}0.033 * * * \\
(8.71)\end{array}$ & $\begin{array}{c}0.032^{* * *} * \\
(8.71)\end{array}$ & $\begin{array}{c}0.032 * * * \\
(8.72)\end{array}$ & $\begin{array}{c}0.031 * * * \\
(8.44)\end{array}$ & $\begin{array}{c}0.031 * * * \\
(8.44)\end{array}$ & $\begin{array}{c}0.031 * * * \\
(8.24)\end{array}$ & $\begin{array}{c}0.031 * * * \\
(8.24)\end{array}$ \\
\hline Constant & $\begin{array}{c}5.297 * * * \\
(10.69)\end{array}$ & $\begin{array}{c}5.293 * * * \\
(10.68)\end{array}$ & $\begin{array}{c}5.342^{* * *} * \\
(11.03)\end{array}$ & $\begin{array}{c}5.338 * * * * \\
(11.02)\end{array}$ & $\begin{array}{c}5.096^{* * * *} \\
(10.33)\end{array}$ & $\begin{array}{c}5.093 * * * \\
(10.32)\end{array}$ & $\begin{array}{c}5.146 * * * \\
(10.62)\end{array}$ & $\begin{array}{c}5.143^{* * *} * \\
(10.61)\end{array}$ & $\begin{array}{c}4.978 * * * \\
(10.01)\end{array}$ & $\begin{array}{c}4.975 * * * \\
(10.00)\end{array}$ \\
\hline Observations & 841 & 841 & 854 & 854 & 847 & 847 & 841 & 841 & 791 & 791 \\
\hline Time FE & $\mathrm{Y}$ & $\mathrm{Y}$ & $\mathrm{Y}$ & $\mathrm{Y}$ & $\mathrm{Y}$ & $\mathrm{Y}$ & $\mathrm{Y}$ & $\mathrm{Y}$ & $\mathrm{Y}$ & $\mathrm{Y}$ \\
\hline $\mathrm{R}^{2}$ & 0.865 & 0.865 & 0.870 & 0.870 & 0.866 & 0.866 & 0.870 & 0.870 & 0.869 & 0.869 \\
\hline
\end{tabular}

This table shows the estimation of RE with AR (1) disturbances of equation (3). See Tables 2-3 for the definition of the explanatory variables. *, ** and *** indicate statistical significance at the $10 \%, 5 \%$ and $1 \%$ levels, respectively. Z-statistics based on robust standard errors are shown in brackets. 